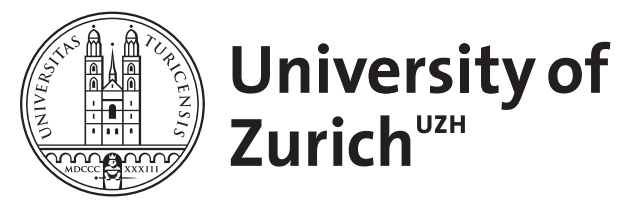

\title{
Traces of Portuguese in Afro-Yungueño Spanish?
}

\author{
Perez, Danae Maria
}

\begin{abstract}
This article sheds new light on the history of Afro-Yungueño Spanish (AY), an isolated variety of Spanish spoken by descendants of slaves in the Bolivian Yungas valleys, and examines the possibility of a Portuguese input to it. First, new ethnographic and historical data are introduced to show that the AY speakers in Mururata, Chijchipa, and Tocaña probably descend from African slaves who arrived in Bolivia during the 18th century from different parts of the Portuguese slave trade area. As this suggests that Portuguese may have been involved in the history of AY, the second part of this paper, after describing some of its particularities, compares AY with Africanized varieties of Portuguese, above all Afro- Brazilian Portuguese, to show that there is evidence to assume that AY is related to certain varieties of Afro-Portuguese. The final discussion considers the contributions of AY to the debates on Afro-Iberian speech varieties.
\end{abstract}

DOI: https://doi.org/10.1075/jpcl.30.2.04per

Posted at the Zurich Open Repository and Archive, University of Zurich

ZORA URL: https://doi.org/10.5167/uzh-118942

Journal Article

Accepted Version

Originally published at:

Perez, Danae Maria (2015). Traces of Portuguese in Afro-Yungueño Spanish? Journal of Pidgin and Creole Languages, 30(2):307-343.

DOI: https://doi.org/10.1075/jpcl.30.2.04per 


\title{
Traces of Portuguese in Afro-Yungueño Spanish?
}

\begin{abstract}
This article sheds new light on the history of Afro-Yungueño Spanish (AY), an isolated variety of Spanish spoken by descendants of slaves in the Bolivian Yungas valleys, and examines the possibility of a Portuguese input to it. First, new ethnographic and historical data are introduced to show that the AY speakers in Mururata, Chijchipa, and Tocaña probably descend from African slaves who arrived in Bolivia during the 18th century from different parts of the Portuguese slave trade area. As this suggests that Portuguese may have been involved in the history of AY, the second part of this paper, after describing some of its particularities, compares AY with Africanized varieties of Portuguese, above all AfroBrazilian Portuguese, to show that there is evidence to assume that AY is related to certain varieties of Afro-Portuguese. The final discussion considers the contributions of AY to the debates on Afro-Iberian speech varieties.
\end{abstract}

Keywords: Afro-Yungueño Spanish, Spanish Creoles, Afro-Hispanic varieties, Brazilian Vernacular Portuguese, Afro-Bolivia, Yungas, Atlantic slave trade

\section{Introduction: Approaching the past of Afro-Yungueño Spanish ${ }^{1}$}

The scarcity of Spanish-lexified creole languages in the Americas has been subject to debates for many years now. In spite of the massive colonial expansion of the Spanish Crown, only two American Afro-Hispanic speech varieties are officially identified as creoles, Papiamentu and Palenquero, and both are considered to be only synchronically Spanish-lexified because they probably originate in a Portuguese creole (Lipski 2005:287). This paucity induced McWhorter to question models of creole genesis in general and to propose the existence of slave trade settlements in West Africa - which Spain lacked - as crucial in the formation of creole languages (2000). However, McWhorter laments the absence of more data to shed light on the issue by stating that

[m]any creolists have long hoped that a Spanish-based creole would turn up spoken by a hitherto unstudied Afro-Hispanic group... However, would not we expect that after all this time, given the obvious fact that the discovery of a new Spanish creole would make

\footnotetext{
${ }^{1}$ I owe an enormous debt of gratitude to Donald Winford, Daniel Schreier, Armin Schwegler, Georg Bossong, Mario A. Della Costanza, Nicole Eberle, Stephan Schmid, Nicolas Lombard, and the anonymous JPCL reviewers for their valuable advice, critique, and support. All shortcomings are my own.
} 
a career, that someone would have found a Spanish creole other than Papiamentu and Palenquero somewhere across the vast expanse of the Caribbean and Latin America? (McWhorter 2000: 31-32; original emphasis)

When McWhorter wrote this thirteen years ago, linguists were mostly unaware of the fact that such a 'hitherto unstudied Afro-Hispanic group' did exist: the small community of African descent in the Bolivian Yungas valleys that speaks such an Afro-Hispanic variety, AfroYungueño Spanish (AY).

Since its 'discovery' in the first decade of the 21 st century, the history and the structural properties of AY were described and analyzed by Lipski (2008a), Perez-Inofuentes (2010a), and Sessarego (2011b). However, there is no agreement on the status and origins of AY. As for its origins, it has not yet been determined satisfactorily when the founder community of AY entered Bolivia and where AY was formed. Lipski traces the roots of AY back to the arrival of the first Africans in Bolivia during the 16th century and proposes that AY may have descended from an Afro-Hispanic pidgin (Lipski 2008a:45). Sessarego (2011b) provides a detailed account of the history of Africans in Bolivia on the basis of the literature and comes to the conclusion that it seems unlikely that a Spanish pidgin or creole ever emerged there because of the small proportion of Africans in an overwhelmingly indigenous society. Further, he argues that linguistic evidence suggests that AY was never a creole but rather an L2 variety of Spanish since its very beginning (2011b:84). Accordingly, even though the discovery of AY did 'make a career', we still do not know what ancestors AY stems from and whether AY supports the existence of an Afro-Hispanic slave trade pidgin as held by Lipski (2008a:186) or not (Sessarego 2011b). Therefore, the present paper adds to the discussion on the origins of AY by proposing a different hypothesis that has not been discussed so far. On the basis of both historical and linguistic data, I submit that the ancestor of AY was not formed in Bolivia but imported by the original slave community during the 18th century from the Portuguese slave trade via the River Plate, and that, similar to Palenquero and Papiamentu, Portuguese was also involved in the history of AY.

The paper's first section gives an account of the sociolinguistic history of the AfroBolivian community and introduces new historical and ethnographic data that indicate that the first members of the AY speech community probably came there via the Portuguese slave trade, which would imply that the founders of AY had been in contact with some variety of Portuguese. This is followed by a brief description of selected AY features that suggest that a reevaluation of the status of AY among Afro-Hispanic speech varieties may be due. The last section returns to the suggested historical relationship between the ancestors of the AY speech 
community and Afro-Brazilian speech communities and discusses the possibility of a Portuguese input to AY by describing certain structural similarities. The discussion reviews the possible contributions of AY to the debates on the origins of Afro-Iberian speech varieties and the potential for future research.

\section{Data and methodology}

The description and argument submitted here are based on roughly eight hours of audiorecordings and a considerable amount of field notes collected during several trips to Bolivia between 2009 and 2013. These data are part of an ongoing research project that is presented here for the first time. I became familiar with the urban Afro-Bolivian community in La Paz in January 2002 while doing voluntary work for a Human Rights organization. In the following three years, I conducted ethnographic fieldwork as I participated in the activities of an Afro-Bolivian movement in La Paz, traveled extensively, and got to know Afro-Bolivians living in different parts of Bolivia. This research is thus rather data-driven than theory-driven, and its principal aim is to document AY and describe its speech community as holistically as possible (Haas 1976:43, Harrison 2009:206). A first sketch of the AY basilect with a detailed historical account of the community on which this paper is based was presented in 2010 without my being aware of the existence of Sessarego's (2011a, 2011b) research (PerezInofuentes 2010a).

AY is difficult to document. The stigmatized status of AY, on the one hand, and potential miscommunication due to (asymmetrical) unintelligibility, on the other, induce AY speakers to avoid using AY in the presence of outsiders - non-Afro-Bolivians, that is. The difficulty of accessing and researching AY can be illustrated by the fact that, initially, the Bolivian linguist Montaño Aragón (1992) suspected the presence of an African language in the Yungas region, but given that his study merely lists a number of unanalyzed divergent Spanish expressions, it is highly likely that he found no such language because the AfroBolivian people addressed him in a Spanish variety that was similar to the regional dialect. The first authentic speech samples were provided by an Afro-Bolivian researcher only, the historian Angola Maconde (2000), who then contributed to the first extensive linguistic study of AY carried out by an 'outsider' (Lipski 2008a). To collect data in the AY speech community, familiarity and confidence prove pivotal.

Therefore, the principal methodological approach of this research was participant observation. My familiarity with the community gave me the privilege of witnessing intimate 
social gatherings and natural, spontaneous conversations among Afro-Bolivians. My prime concern was always to avoid the uneasiness of the speakers and the effects of the Observer's Paradox (Labov 1972:209). The contributors to this project are themselves members of the AY community, and the most considerable contribution was made by a 1971-born member of the Chijchipa community, who assisted this research project since its inception as a valuable fieldwork assistant, as well as a 1990-born student from Mururata, with whom I carried out a number of interviews. A total of 31 AY speakers from Mururata, Chijchipa, and Tocaña born between 1920 and 1971 were recorded. Table 1 gives the basic information of the 31 informants distributed into three age groups.

\begin{tabular}{|l|l|l|l|l|l|l|}
\hline Village & \multicolumn{2}{|c|}{ Mururata } & \multicolumn{2}{c|}{ Chijchipa } & \multicolumn{2}{c|}{ Tocaña } \\
\hline Gender & Female & Male & Female & Male & Female & Male \\
\hline $1920-1940$ & 0 & 1 & 2 & 1 & 3 & 1 \\
\hline $1941-1960$ & 2 & 1 & 2 & 1 & 3 & 3 \\
\hline $1961-1990$ & 2 & 1 & 4 & 2 & 2 & 0 \\
\hline
\end{tabular}

Table 1: Audio-recorded AY speakers by gender and age group.

The audio-recordings represent spontaneous conversations among Afro-Bolivians that were recorded when one of the two contributors mentioned above carried the recording device, a proceeding which, logically enough, provided the most authentic speech samples. However, it must be pointed out that the data are very heterogeneous in nature because there are short sequences of a few minutes only and others of more than one hour, and the topics and settings vary. The recordings showed that the ethnic origin of the interlocutor as well as the topic of conversation frequently influenced the variety used by the speakers. In a notebook, I collected field notes when the presence of a microphone would have been inappropriate (in fact, most of the time), or when the recording device was not available. As a method, participant observation was essential not only to complement the linguistic data with unrecorded samples, but also to understand the social and cultural functions of AY. The flip side of this combination of different methods is that representative quantitative analyses are made impossible. In my view, nonetheless, working with both audio-recordings and field notes is the only way of documenting the last basilectal vestiges of this rapidly vanishing African-Iberian speech variety.

\section{Unraveling the past of the AY speech community}


Today, the Afro-Bolivian population consists of roughly 20,000 individuals spread throughout the country. Most Afro-Bolivians trace their roots back to the Yungas valleys in the provinces of Nor Yungas and Sud Yungas to the Northeast of La Paz. However, only a very limited number of the Afro-Bolivian population actually speaks some variety of AY, that is, only those Afro-Yungueños who grew up in a predominantly Afro-Yungueño community in the Yungas region. The vast majority of the Afro-Bolivian population does not speak AY. Rather, they speak the regional varieties of vernacular Bolivian Spanish according to the place where they live. For this reason, I advocate the designation Afro-Yungueño instead of Afro-Bolivian Spanish (Lipski 2008a, Sessarego 2011a).

As Afro-Bolivians affirm unanimously that the most cerrado 'closed' - what linguists would call 'radical' - variety of AY is spoken in Mururata, it seems reasonable to take the Mururata variety as the basilect and 'point of departure' (Alleyne 2000:126). Moreover, along with Winford (2000:218), I consider it most useful to inquire into the past of one small variety on a micro-level first, before drawing conclusions on a larger group of related varieties. Accordingly, this research project focuses exclusively on the speakers and varieties of three closely connected rural Afro-Bolivian communities where AY is still in use, the village of Mururata and nearby Chijchipa and Tocaña in the province Nor Yungas. The total population of African descent of these three villages in 2010 was approximately 200 (Perez-Inofuentes 2010a:25-26).

Even if their exclusive status among the mainly indigenous population of Bolivia has attracted considerable academic interest, little data is available on the origins of the AfroBolivian community in the Yungas valleys. The first attempts to trace their roots were made by historians such as Crespo (1995 [1977]) and Portugal ${ }^{2}$ (1977) who sought to determine the ethnic origins of African slaves in Bolivia on the basis of legal documents, and to describe their living conditions in colonial society. While these living conditions are relatively well documented (Bowser 1974; Bridikhina 1995; Brockington 2009), the ethnic and linguistic origins of the African slaves could not be determined satisfactorily. On the one hand, this is due to Bolivia's geopolitical position in the South American hinterlands. In colonial times, Bolivia - then called Alto Peru - first belonged to the viceroyalty of Peru and was administered and accessed from Lima. Accordingly, most of the African slaves were imported through the port of Callao in Peru. However, slaves were almost unaffordable in Bolivia in those times, and most of them worked individually as domestic servants (Crespo 1995:103).

\footnotetext{
${ }^{2}$ Readers familiar with the literature on Afro-Bolivians may ask why I exclude Pizarroso Cuenca (1977) from this account. As I argue elsewhere (Perez-Inofuentes 2010b:52), I think that this author's distant view of the Afro-Bolivian community is guided by racist ideas and does not provide new insights.
} 
Consequently, the first generation of African slaves quickly disappeared through miscegenation. In the 18th century, Bolivia was included in the Río de la Plata viceroyalty and was henceforth not only governed by Buenos Aires, but also accessed mainly via the River Plate. These two possible slave trade routes, either through Peru or via the River Plate, have made it exceedingly difficult to determine the origins of the Bolivian slaves. Knowledge of the exact importation route would help advance research on the topic but, unfortunately, documentation of these routes does not appear to exist.

On the other hand, the progress of historical research has been hindered by retrograde ideas that persist in Bolivian society. The extinction of Africans in colonial Potosi, for example, is usually explained by the supposed unfitness of Africans for the Andean altitude (Busdiecker 2006:92, Perez-Inofuentes 2010b). The Bolivian linguist Montaño Aragón (1992) attempted to contribute new insights into the past of the Afro-Bolivians by comparing their physical phenotypes to West African ethnic groups. More importantly, as the Afro-Bolivian identity is partly grounded on the hardships suffered by the slaves who perished in the silver mint of Potosí, most urban Afro-Bolivians themselves claim to descend from Africans who arrived in Bolivia in the 16th century. Accordingly, urban Afro-Bolivian movements such as the Movimiento Cultural Saya Afroboliviano as well as Afro-Bolivian authors such as Angola Maconde (2000) and Rey Gutiérrez (1998) seek evidence of their origins in the 16th century. Later, foreign anthropologists such as Busdiecker (2006) also focused on the arrival of the first Africans in Alto Peru in the 16th century. Since none of these works explains the arrival of the first African slaves in the Yungas region, the question of the origins of the AY speech community has not been answered.

The same state of knowledge serves as a basis for the first book on AY Afro-Bolivian Spanish (Lipski 2008a). Given that the first African slaves entered Alto Peru as early as the mid-16th century, Lipski assumes that AY stems from a 16th century Afro-Hispanic language which was 'formed in situ over four centuries ago' (2008a:45; original italics). This explains neither the origins of the AY speech community nor the location where AY was formed. The most detailed accounts of the first arrival of African slaves to the Yungas regions are provided by Perez-Inofuentes (2010a) and Sessarego (2011b). On the basis of a thorough study of the literature, both researchers conclude independently that, according to the available historical documentation, the first African slaves probably arrived in the Yungas valleys during the 18th century to work on the coca plantations of the Mururata hacienda (Crespo 1995:137), and that it is very unlikely that the original African-Bolivian population, which was employed individually as domestic slaves throughout the country, would have spoken a more widely 
used Afro-Hispanic pidgin (Perez-Inofuentes 2010a:39-40, Sessarego 2011:44). However, Sessarego's account (2011b) also begins in 16th century Bolivia. An 18th century origin of the first African slaves at the Mururata hacienda, coupled with the fact that the most profoundly restructured variety of AY was maintained on the Mururata hacienda, nevertheless, suggests that research should focus on the Mururata location, since historical demographics relating to periods earlier than the 18th century do not contribute new insights into the past of the AY speech community. The present research therefore focuses exclusively on the Mururata community and its neighboring villages Chijchipa and Tocaña, and the account given here may therefore not be applicable to other Afro-Bolivian communities.

Different approaches included in this research project reveal additional details on the origins of the community of African descendants in the Yungas valleys. For example, documents kept by the family that currently owns the Mururata hacienda provide more insights. These documents indicate that the first group of about twenty African slaves was acquired in Potosi in the early 1730s and then taken to Mururata to work on the hacienda's coca plantations. ${ }^{3}$ Given that most of the African slaves who were sold in Potosi had been traded in Buenos Aires (Crespo 1977:44ff), it seems reasonable to assume that the AfroYungueño community also arrived by way of the River Plate. In addition, there are AfroBolivian cultural practices that suggest a connection to the River Plate: the Semba dance, the veneration of San Benito, and the Afro-Bolivian King. ${ }^{4}$ The name of the Semba dance stems from Kimbundu kuzemba 'navel' (Ortiz Oderigo 2007:189) and refers to the particular ombligada, whereby dancers thrust their bellies together, navel touching navel. Whilst this dance is also found among other communities of African descent in the River Plate region, there is no mention of it in the literature on African-Peruvian communities. Similarly, San Benito, the saint of the Afro-Bolivian community of Mururata, is also present in African communities in Buenos Aires (Studer 1958:336; Ordiz Oderigo 2008:56), whereas the African population of Lima venerated San Martín de Porres (Bowser 1974:243). The same is true - although not exclusively so - in the case of African kings: both Afro-Argentine and Afro-Brazilian communities elected kings (Ortiz Oderigo 2008:56-57; Mello e Souza 2002), and the last king in Mururata was Bonifacio Pinedo, whose heir to the throne today is his

\footnotetext{
${ }^{3}$ This piece of information can be found in Cariaga's novel Mururata (2008). I interviewed Juan Cariaga together with a student from Mururata in February 2010 to know more about the reliability of his sources.

${ }^{4}$ Lipski (2008a:34) claims that "there are no other [except Saya and Mauchi] demonstrably "modern" AfroAmerican practices or beliefs in the traditional Afro-Bolivian communities', which could provide information on the origins of the AY speech community (this assumption is also adopted by Sessarego 2011:35). The cultural practices of the Afro-Bolivian culture - most of which are now performed for political or commercial reasons only - are the Saya and the Semba dances, the Baile de Tierra, and the funeral ritual called Mauchi which was mainly practiced by the people from Tocaña who visited the surrounding communities to assist funerals. The last two original performers of Mauchi passed away in 2012 at the age of 90 and 92.
} 
grandson Julio Pinedo. Finally, a 1922-born informant from Tocaña recalled that their ancestors had arrived from Brazil (Perez-Inofuentes 2010a:47). This small piece of oral history is consistent with the ethnographic and historical evidence indicating the arrival of the Afro-Yungueño community by way of the River Plate during the 18th century, a finding that allows us to apply the literature on the African slaves in Buenos Aires to the Afro-Yungueño community.

According to Studer (1958:324-325), the vast majority of the slaves who passed through the River Plate during the 18th century came from Brazil and Africa. A total of 12,473 slaves arrived from Brazil, and the most important slave trading port was Rio de Janeiro, from where 5,611 were brought to the River Plate. Santos, Pernambuco, and Bahia also sent slaves to the River Plate. The main African ports that shipped slaves to Argentina were Mozambique with 3,935 slaves, followed by Guinea ${ }^{5}$ with 3,040 slaves and Angola with 2,742. The total number of slaves from Africa amounts to 13,460 . However, these numbers can only provide a general idea of the slaves' origins, for a much greater number arrived without further documentation. A letter written by the Jesuit priest Ignacio Chomé in Corrientes in 1730 provides further details: 'there are more than twenty thousand blacks in Buenos Aires who ... don't know the Spanish language. Since most of them are from Angola, Congo, and Loango, I felt like learning the language of Angola, which is in use in these three kingdoms' (cited in Mühn 1946:145, my translation and emphasis). This valuable piece of information indicates that the African slaves who arrived in Bolivia during the 18th century probably did not speak Spanish. Rather, they spoke either African languages - most probably of the Bantu family, which would be consistent with the origin of the Semba dance and the Afro-Bolivian family names Angola and Maconde - or some variety of the language of their slave traders. Moreover, Father Chomé speaks of only one language, which suggests that the Africans in Buenos Aires in 1730 were a relatively homogeneous group. Given that all these Brazilian and African ports were generally run by Portuguese-speaking slave traders, it is likely that the African slaves who arrived in Potosi and the Yungas region in the 18th century after their long journey had some knowledge of Portuguese (Perez-Inofuentes 2010a).

Due to the abundance of unsold slaves in the River Plate region during the 18th century, the acquisition of slaves had become affordable in the hinterlands (Studer 1958). At the same time, there was an increasing demand for coca leaves in the Bolivian mines, and African slave labor on coca plantations was suddenly much sought after. In the early 1730s, the owner of the recently built Mururata hacienda acquired some twenty African slaves

\footnotetext{
${ }^{5}$ Studer (1958:325) specifies that 2,207 originated from 'Bonny' and 'Nueva Calabar', whereas 813 came from an undocumented place.
} 
'strolling around' (Cariaga 2008:78; my translation) to work on her hacienda's coca leaf plantations. At the end of the century, over 100 African slaves worked together with indigenous wage laborers on the hacienda (Crespo 1995:134). In those times, the only means of transportation between La Paz and the mountainous and densely wooded Yungas region were mules, and Mururata - at approximately 100 miles from La Paz - was especially difficult to reach. Mururata's slaves lived in a couple of mud huts close to the hacienda in an isolated corner called La Calle (Perez-Inofuentes 2010a).

Although they worked in the immediate vicinity of indigenous co-workers in the coca fields, the African slaves were kept isolated. Following Schreier's (2009:682ff.) definition of isolation as a sociolinguistic construct, the isolation of the African community in Mururata was three-fold: geographic, social, and attitudinal. In addition to their geographic seclusion, the African slaves were separated from their indigenous peers by a profound feeling of animosity, which still persists to some degree today. ${ }^{6}$ This feeling was not only aroused by ethnic differences and a lack of mutual understanding, but also provoked deliberately by the Spaniards who feared land claims and massive uprisings by the indigenous population (Spedding 1994:134). For this reason, the hacienda owners tried to keep the monolingual Aymara-speaking indigenous workers apart and housed them in another village called Santa Gertrudis, and the acullicus, the short interruptions at work in the coca field, were held separately for each group (Crespo 1995:125). Their African slaves, in contrast, lived close to the hacienda, were baptized in its adjacent chapel, and were addressed in Spanish. ${ }^{7}$ The Spanish spoken by the slave overseers, however, was likely to consist of many Aymara items as well as L2 Aymara, which may be one of the reasons for the high number of Aymara items in AY (Perez-Inofuentes 2010:82-83). As older informants from Mururata of both ethnic backgrounds confirm, the African and indigenous population of Nor Yungas had little common ground, and while the Aymaras spoke little or no Spanish, Afro-Bolivians had a very limited knowledge of Aymara. Moreover, the hacienda owners lived in La Paz and visited their property only sporadically, leaving their overseers in charge. This linguistic isolation and conservatism can be attested in the preservation of Spanish archaisms such as the $/ \mathrm{h} / \mathrm{sound} \mathrm{d}^{8}$ in words as hartu 'much' and hidi 'to stink' or the item caja 'drum' instead of tambor. In brief, the African community in Mururata lived in a situation of isolation bearing certain similarities to maroon villages, such as El Palenque de San Basilio where Palenquero is

\footnotetext{
${ }^{6}$ The repertoires of offensive designations in both Aymara and AY attest to this.

${ }^{7}$ Afro-Yungueños are proud to be católicos. However, this does not imply that the slaves were treated gently.

${ }^{8}$ Archaic word-initial /h/ was only found in words that do have an etymological $/ \mathrm{h} / \mathrm{such}$ as jurmiga from hormiga 'ant'. The data do not show instances of hypercorrect, 'unetymological' $/ \mathrm{h} /$-insertion. The same phonological feature is found in Cuban bozal Spanish, as, for example, jurumiga (Lipski 2005:149).
} 
spoken (Schwegler 1998:220) or the Afro-Brazilian quilombos (Lucchesi et al. 2009:75), which favored the independent evolution and conservation of AY.

The neighboring Afro-Bolivian communities of Chijchipa and Tocaña have a similar past. On those haciendas, the African and indigenous communities were equally divided in separate villages. As the three haciendas were located within walking distance, the people from Mururata, Chijchipa, and Tocaña often met to either work together (on the basis of the Aymara work exchange system called ayne $e^{9}$ or to celebrate religious rituals and the AfroBolivian Saya dance. To a lesser extent, they were also in contact with other Afro-Bolivian communities in other parts of the Yungas provinces. Intermarriage with indigenous people was rare. ${ }^{10}$ Thus, while keeping up a strong black ethnic identity (Busdiecker 2006), AfroYungueños were usually rather reserved towards Aymaras. This situation of isolation resulted in the African community of the province of Nor Yungas being endocentric and endogamous until the second half of the 20th century, which may have favored the maintenance of AY in Mururata, Chijchipa, and Tocaña for nearly 200 years.

Nevertheless, Mururata, Chijchipa, and Tocaña are no longer isolated communities. The most significant changes were introduced after the Agrarian Reform in 1953: the hacienda system was abolished, and Bolivia's African and indigenous peons were liberated from labor exploitation. Soon, the village of Mururata was built in a more accessible place close to the road, and for the first time indigenous and African Yungueños lived in the same village. Also Chijchipa experienced major changes when its hacienda and land were bought by its new owner - a former president of the Republic - and the entire Afro-Bolivian community of Chijchipa was relocated closer to Mururata. After the beginning of the rural exodus in the 1970s, ${ }^{11}$ many Afro-Yungueño peasants left their homes to look for new opportunities in the cities of La Paz and Santa Cruz or in Caranavi and the Beni Department. Moreover, local schools were established in almost all rural communities, a change which not only significantly increased the literacy rate among young AY speakers, but also meant that children were admonished for speaking non-standard varieties of Spanish. Soon, both AfroBolivian as well as Aymara children attending school together spoke L2 varieties of Spanish.

\footnotetext{
${ }^{9}$ Ayne (pronounced as ayni in AY and Aymara) is the traditional way of cooperating among yungueños. In order to harvest the ripe crop or coca leaves as quickly and efficiently as possible, a group of workers (usually relatives and close friends) cooperates on a reciprocal and rotating basis. These get-togethers are crucial to build and keep strong ties among community members. Elderly AY-speakers recall that, in some cases, they would rather do ayne with Afro-Bolivians in villages as distant as Chicaloma in Sud Yungas than with their immediate Aymara neighbors. However, once a year, these 'teams' would get together on a single coca field to compete against one another.

${ }^{10}$ In the province of Sud Yungas, ethnic intermarriage started much earlier (Leons 1978). For a detailed analysis of the organization of difference in Bolivia with regard to Afro-Bolivians, see Busdiecker (2006).

${ }^{11}$ This exodus was, among other reasons, the consequence of the limited amount of land that could be inherited by the generation following the Agrarian Reform.
} 
Without a doubt, these political, cultural, and social changes experienced by the AY speech community during the second half of the 20th century had far-reaching sociolinguistic consequences.

Since the beginning of the 21 st century, the community's contact with the outside world has continually increased. Cell phones are readily accessible, and public transportation to Coroico and La Paz is available on a daily basis. Community members who now live in other parts of Bolivia or even outside Bolivia often contact and visit their relatives at home in Nor Yungas. At the same time, television has reached all households, and international telenovelas (soap-operas) are an integral part of rural everyday life. In addition to the basic education available in all the villages, many Afro-Bolivians graduate at the recently established rural academy of the Bolivian Catholic University in nearby Coroico, or at institutes of higher education in La Paz. ${ }^{12}$ Finally, the region's natural resources and AfroBolivian music and culture attract the interest of national and international visitors, and Tocaña, in particular, is inundated with tourists. ${ }^{13}$ This new situation has led to a mingling of local and foreign cultures, which not only brings about linguistic interferences with other varieties of Spanish, but also a significant diversification of the topics and settings of conversations. All these changes have marginalized the use of AY, a variety intimately connected to its social and natural environment. Basilectal AY is seldom used (even elderly speakers now speak principally their L2 influenced variety of Spanish), and AY crops up only occasionally, especially when speaking to relatives and children. The younger generations speak the regional variety of Spanish and use AY as an ethnic dialect in interactions with other community members. In total, only a handful of individuals in Mururata, Chijchipa, and Tocaña today can still be considered speakers of AY.

In brief, the historical and ethnographic data point to the conclusion that today's AY speakers in Mururata, Chijchipa, and Tocaña are descendants of African slaves who arrived in the Bolivian Yungas valleys during the 18th century from different locations within the Portuguese slave trade area. The assumption that the original slaves brought their speech variety with them to Mururata is in line with Lipski (2008:185), although I do not believe that AY stems from an Afro-Hispanic pidgin that already existed in 16th century Bolivia. Rather,

\footnotetext{
${ }^{12}$ There are various international organizations that grant scholarships to Afro-Bolivian and indigenous students, a fact that has significantly increased the number of graduate professionals among AY speakers.

${ }^{13}$ The situation of the Afro-Bolivian community is likely to be similar to what is happening in Palenque, where the Afro-Colombian community is receiving considerable attention (Schwegler 2000:414, 2002:143). Many tocañeros, the inhabitants of the most visible Afro-Bolivian village where most researchers, tourists, and journalists arrive, have turned into what Agar called 'professional stranger handlers' (2008:135). Considering their ethnic consciousness when representing their community, they may have adapted their speech in some way. It is hence important to say that I also worked with people from Tocaña who are not used to frequent contact with 'outsiders'.
} 
because the slaves introduced to the Yungas probably originated in different Portuguese slave trade settlements in the Atlantic area, above all Brazil and Angola, it seems more likely that they spoke either a language of the Bantu family and/or had some knowledge of Portuguese or a contact language derived from Portuguese. This common origin of Afro-Bolivians and Afro-Brazilians from the Portuguese slave trade suggests that their language varieties may be related not only with regard to their African substrate languages but also with regard to Portuguese. The community's social, geographic, and attitudinal isolation then probably favored the maintenance and independent evolution of AY until the middle of the 20th century when profound social and sociolinguistic changes began to accelerate the process of decreolization and marginalization of AY. The history of the AY speech community hence parallels that of Afro-Brazilian communities (Lucchesi et al. 2009:75) not only in their common origin, but also in that they a) consisted nearly exclusively of descendants of African slaves, b) lived in isolation from the 18th until well into the 20th century, and c) depended on subsistence farming until the end of the last century.

\section{Afro-Yungueño varieties}

The status of AY - as, in fact, the concept of a creole language in general - has not yet been determined unanimously. Lipski identifies AY 'at the very least ... as a semicreole' (2008:196) that may stem from a former Afro-Hispanic pidgin (2008:186) and specifies that '[o]n the creole "thermometer", Afro-Yungueño Spanish probably falls just below Cape Verde crioulo' (ibid:183, original italics). He bases his argument on several features generally accepted as indicative of creole status such as null definite articles, ${ }^{14}$ invariant verb forms, double negation, non-inverted questions, or absence of gender concord in the noun phrase (2008:184), which are all present in AY and confirmed by my data. Sessarego (2011b), in response, postulates that AY is best considered an L2 variety of Spanish that is not decreolizing from a formerly more restructured Afro-Hispanic variety. He argues that certain AY features can rather be attributed to naturalistic L2 acquisition that appeared in the course of the isolation of the community. I agree that L2 acquisition was important in the history of $\mathrm{AY}$ as it is an integral part of processes of language contact and contact-induced language change. However, my data challenge Sessarego's position of considering AY an L2 variety of Spanish. In fact, in the light of its sociolinguistic history as an African-American variety of Spanish that experienced intense language contact, as well as its linguistic features that

\footnotetext{
${ }^{14}$ This term refers to the lack of definite articles in subject position, which normative varieties of Spanish require. The same feature is observed in Palenquero (Lipski 2008:84).
} 
distinguish it considerably from the acrolect, I would rather agree with Lipski. In what follows, I try to explain this position and sketch the current situation of AY and its contact with Andean Spanish.

First and foremost, however, it must be pointed out that AY is not a homogeneous speech variety. Along with the growth of the community's heterogeneity in terms of formal education, occupational activities, and contact with foreigners due to emigration, tourism, and intermarriage, the decreolization and internal fragmentation of AY have become particularly manifest. Speakers born after the community's opening in the 1970s hardly use basilectal AY but do have an awareness of generational differences and recall their parents and grandparents using a very divergent variety of their dialect. ${ }^{15}$ This awareness of generational differences, coupled with the community's social history of isolation until 1953 and its endocentricity until the 1970s, suggests that AY is decreolizing quickly from a formerly more restructured basilect. On the other hand, it is important to consider that the Spanish variety spoken in the region and toward which many AY speakers shifted is itself a variety that is characterized by language contact and naturalistic L2 acquisition. ${ }^{16}$ In order to describe this relatively chaotic linguistic reality, I distinguish between three different lects, all of which are spoken by AfroBolivians but diverge in structural and functional properties: the AY basilect, the mesolect, and Afro-Bolivian post-creole varieties of Spanish influenced by L2 acquisition. After outlining the differences between these varieties, the argument presented here focuses on the most basilectal variety of AY because it is more likely to represent earlier stages of AY. The examples, nonetheless, as most utterances in AY, display both basilectal and mesolectal features.

Basilectal AY is, in my view and in line with Lipski (2008a), more divergent from Spanish than the varieties categorized as semicreoles by Holm (2004), as, for instance, Caribbean vernaculars. As will become more apparent throughout this paper, several categories were reorganized on the basis of the features that were available in the languages involved (Mufwene 2001). Consequently, AY stands out from its linguistic environment on all levels. Its phonology, morphosyntax, and lexicon diverge considerably from any

\footnotetext{
${ }^{15}$ A 1922-born informant from Tocaña once stated that her grandparents had spoken Portuguese (PerezInofuentes 2010a:38).

${ }^{16}$ Most of the population surrounding the AY speech community is bilingual in Spanish and Aymara (in the 2001 census, $51.3 \%$ of the Nor Yungas population indicated Aymara as their L1), and hence the Spanish variety spoken in the region is highly influenced by the Aymara substrate and processes of irregular L2 acquisition. For example, variation in number and gender agreement in the noun phrase can also be observed in the variety of Spanish spoken by Aymara-speakers.
} 
vernacular variety of Spanish spoken in Bolivia. ${ }^{17}$ As for its phonology, the most characteristic features of AY are the simplification of the syllable structure to $\mathrm{CV}$ as in muhe $^{18}$ [Sp. mujer] 'woman', the substitution of /f/ by /xw/ as in jweria [Sp. feria] 'fair', the raising of unstressed /e/ and /o/ to [i] and $[\mathrm{u}]$, and the realization of the voiced fricatives $/ \beta /$ and $/ \delta /$ - if realized at all - as voiced plosives $/ \mathrm{b} /$ and $/ \mathrm{d} /$. The most recognizable feature of basilectal AY, however, is its prosody, above all the extreme pitch movements and vowel lengthening in combination with high pitch or falsetto voice quality (Perez-Inofuentes \& Zipp, in prep.) For example, it is very common to use high pitch to emphasize or contextualize an utterance. The high pitch and lengthened vowels (marked in bold) in the phrase Nohotro ganai pescau grave! 'We [felt] acute desire for fish' emphasize the utterance (and add a mocking tone to it), and they contextualize the speaker as craving fish similar to strategies of reported direct speech. These phonological properties distinguish AY noticeably from any Bolivian variety of Spanish, especially the one that surrounds AY in the Bolivian highlands, which tends to omit vowels and favor consonant clusters. Coupled with the particular AY lexicon, these features make AY exceedingly difficult to understand even for native speakers of Spanish. In addition, the raising of /e/ and /o/ as well as the open syllable structure are, in fact, similar to phonological processes in BVP.

The morphosyntax of basilectal AY differs noticeably from Spanish. The pronominal paradigm sets an example:

$\begin{array}{llll}1 \text { (1) } & \text { yo }(\mathrm{mi})^{19} & 1 \mathrm{pl} & \text { nohotro } \\ 2 \mathrm{sg} & \text { oté } & 2 \mathrm{pl} & \text { otene } \\ 3 \mathrm{sg} & \text { ele } & 3 \mathrm{pl} & \text { eyu }\end{array}$

The use of the pronouns $m i$ and oté is restricted to the most basilectal variety of AY spoken in Mururata and Chijchipa. In Tocaña, the most common 2sg pronoun is bo from Spanish or Portuguese vos, and vos is usually used in post-creole varieties of AY. The pronoun tú seems to be non-existent in AY originally. Oté probably stems from Spanish usted, and the form uté was already documented in 19th century Rio de la Plata Afro-Hispanic speech (Carricaburo

\footnotetext{
${ }^{17}$ For a morphosyntactic analysis of the Spanish variety spoken in nearby La Paz by Aymara-speakers, for instance, see Mendoza (1991).

${ }^{18}$ To present the examples coherently, they are transcribed etymologically and according to the Spanish orthography. The phonetic divergences between AY and the local Andean variety of Spanish are adapted as follows: $<\mathrm{j}>$ for $/ \mathrm{x} / ;<\mathrm{h}>$ for $/ \mathrm{h} / ;<\mathrm{y}>$ for $/ \mathrm{j} /($ Spanish $<\mathrm{ll}>$, in Andean Spanish always realized as $/ K /$ ). To avoid confusions, the etymological mute Spanish $<\mathrm{h}>$ is omitted, and $/ \mathrm{w} /$ is transcribed as $<\mathrm{w}>$.

${ }^{19}$ This pronoun was only once unambiguously recorded in spontaneous speech (example 8f). However, AY speakers from Mururata and Chijchipa later confirmed that it used to be more common before.
} 
1999:164), which would provide further evidence of a connection between the two varieties. ${ }^{20}$ Ele probably stems from Portuguese ele because the addition of final vowels to avoid final consonants, such as ayere from Spanish ayer 'yesterday', is relatively rare in AY. The plural otene arguably originates in Spanish usted with a substratal pluralizer, such as ané from Kikongo (Jacobs 2010: 328-329), which is also present in certain West African creoles and Papiamentu, and which would, as well as the pronoun mi, connect AY with the Portuguesebased creoles in West Africa. However, this assumption is still very tentative and shall be scrutinized in future analyses.

In addition, there are also other AY features that resulted from processes of restructuring. Detges (2000) explains that creolization implies two types of structural change, grammaticalization and reanalysis. The former is the process of attributing new functions or meanings to certain items on the basis of a more differentiated use, such as the case of fini in French-lexified creoles that has acquired a variety of functions related to the meaning of FINISHEDNESS (Detges 2000:143). Reanalysis, on the other hand, refers to the emergence of new markers or other items on the basis of frequent collocations in sound chains or phrases, which often brings about a change in word class and function of an item, such as te/ti from était à 'was just about to' that became a functional marker of IMPERFECT because of its frequent appearance and association with temporal adverbs such as l'autre jour (Detges 2000:153). An example of reanalysis in AY is the pronoun limpiu 'all', which stems from the Spanish adjective limpio 'clean'. Following Detges' approach of considering cognitive processes of association and collocation as crucial in creolization, it is possible that the slave overseer demanded that the coca field be todo limpio 'all clean' after harvesting the leaves, and that this frequent collocation favored the association of the two items, which then brought about the replacement of todo by limpio. The original adjective turned into a pronoun as the following examples illustrate:

a. Lu awelo acabó di morí limpiu.
PL grandfather finished.3SG die all
'All the grandfathers have died.'
b. Río e di limpiu
river be.3SG of all
'It is everybody's river.'
c. limpiu cosa

\footnotetext{
${ }^{20}$ However, these pronouns do also occur in other Afro-Hispanic speech varieties, such as bo and uté in Palenquero (Schwegler 2000:429) or oté in Cuba (Clements 2009:90).
} 


$$
\text { all thing }
$$

'everything'

Sentence (2a) arguably also provides a case of grammaticalization. Even though, at present, AY does not appear to have an elaborate system of TMA markers, the verb acabó (di) 'just finished' may be a case of structural change parallel to fini in French-lexified creoles because the Spanish verb acabar de 'finish' refers to an event that was concluded immediately before another one and can therefore easily be associated with FINISHEDNESS. Thus, there is evidence that basilectal AY underwent considerable restructuring, that is, probably both grammaticalization as well as reanalysis.

These items are, however, not the only reanalyzed and grammaticalized independent markers in AY. Regarding the structure of questions, for instance, Lipski (2008a:135) notices the presence of non-inverted questions in AY, which supports his claim of considering AY the descendant of an Afro-Hispanic pidgin. Non-inversion is indeed a possible structure in AY interrogative clauses. However, AY speakers very frequently use pue from the Spanish adverb pues 'thus' to mark questions, which is another instance of the use of independent particles to express grammatical meaning. This marker is usually posed after the pronoun or at the end of the question as in examples $(3 \mathrm{a}-\mathrm{c})$ :
a. Tatai
quién
pue
era?
father.of
who
INTERROG
was.3SG
'Whose father was he?'
b. Tío Ramón taba
pue?
Uncle Ramón was.3SG
INTERROG
'Was Uncle Ramón there?'
c. $\mathrm{Pa}$ qué pue tas escondendo?
for what INTERROG be.2SG hide.GERUND

'Why are you hiding?'

Adding this evidence to the features analyzed by Lipski, who holds that AY is the most radically restructured variety of Spanish spoken natively, not only in the contemporary Spanish-speaking world, but in all of the known history of the Spanish language' (Lipski 2008a:186), I argue that AY was originally more deeply restructured than has so far been acknowledged, and that although it is not as prototypically Creole-like as Palenquero or 
Papiamento, the option of categorizing basilectal AY an 'intermediate' creole should not yet be excluded.

Because it is mostly restricted to speakers who were born before the beginning of the rural exodus in the $1970 \mathrm{~s}$, basilectal AY is likely to disappear within the next decade. A more vital variety of AY, in contrast, is what I would categorize as the mesolect. Mesolectal AY is used by nearly all Afro-Bolivians from these three villages in rural and, occasionally, urban settings. It is less restructured and used in informal contexts mainly in the absence of outsiders. Similar to the basilect, mesolectal AY is used in conversations on topics of shared knowledge and values such as gossip, jokes, and anecdotes or memories. This variety is principally characterized by the presence of distinctive phonological, prosodic, and lexical features, while divergent morpho-syntactic structures such as the reduced verbal paradigm (see description below) occur only rarely. Most of the younger AY speakers are proficient in both mesolectal AY and the regional variety of Spanish and employ AY as a marker of ethnic identity to express in-group belonging or to exclude outsiders. ${ }^{21}$ As the almost exclusively Spanish- and Aymara-derived vocabulary makes it difficult to distinguish between AY and the regional Spanish variety, it is usually the phonological features of AY, above all the high pitch and open syllable structure, as well as SVO word order, ${ }^{22}$ which help to determine the moment of a code-switch.

Unlike basilectal and mesolectal AY that are clearly distinct from local varieties of Spanish, there is also one variety of AY that results from the contact of AY speakers with Aymara-influenced Spanish. Many mostly illiterate Afro-Bolivians who were born before 1970 and who shifted from AY to the regional variety of Spanish over their lifespan to address outsiders, including their employers, use L2 varieties of Spanish with some features of AY. These varieties are characterized by fossilized features of second language acquisition, for example, variation in gender and number agreement (as opposed to a highly reduced use of grammatical gender in basilectal AY). They show only a few distinctive AY structures such as certain phonological particularities (the /xw/ phoneme replacing /f/), lexemes, and independent discourse markers such as emphatic hay or ba. However, even though they are spoken by Afro-Bolivians and display AY features, most of the properties of this variety are also common to the Spanish variety spoken by the neighboring Aymaras and correspond to the local vernacular variety of Spanish, the target language of AY speakers. I therefore propose to consider these varieties the post-creole varieties of AY.

\footnotetext{
${ }^{21}$ Mesolectal AY is also employed on social networks on the Internet.

${ }^{22}$ Unlike AY, Aymara-influenced Spanish tends to place the verb at the end of the sentence favoring SOV word order (Mendoza 1991:125-126).
} 
In the light of this general picture of AY and its history, which shall be further elaborated on in the future, I advocate that basilectal AY suggests the existence of a more deeply creolized speech variety once spoken in the Yungas valleys. The involved donor varieties were a) an Afro-Portuguese contact variety imported by some of the slaves, b) African substrate languages (one of which was probably Kikongo), c) the (18th century) Spanish lexifier, and d) the Aymara adstrate spoken by the indigenous community and (as an L2) by the slave overseers. I argue that most of the slaves contributed to AY by learning Spanish naturalistically and transferring substratal features from African languages into it. At the same time, a considerable proportion of the slaves seem to have spoken a contact variety of Portuguese and transferred some features of that variety into AY. AY originated from this contact scenario and evolved independently until the abolition of the hacienda system in 1953. Since then, it has experienced rapid decreolization towards the local variety of Spanish, Aymara-influenced Andean Spanish, which is itself a contact variety and which makes the description of earlier forms of AY considerably more difficult.

This view is not entirely concordant with earlier studies on AY. Lipski, in fact, does not exclude the possibility of a more restructured, creole-like ancestor of AY, yet in the absence of more airtight evidence, his conclusion remains tentative (Lipski 2008a). Sessarego (2011b), on the other hand, argues that there is no creole in the ancestry of AY. Nevertheless, both researchers do not discuss certain basilectal features that I consider crucial for the categorization of AY, such as the item limpiu or the interrogative particle pue. Instead, Sessarego analyzes decreolizing structures of AY, such as highly variable gender agreement in todo la (Sessarego and Gutiérrez-Rexach 2011:68) that usually corresponds to basilectal limpiu, and explains that 'even in its most basilectal variety, this dialect would be perfectly intelligible to any standard Spanish speaker' (Sessarego 2011:137). This picture is, in my view, not applicable to basilectal AY and suggests that Sessarego's analysis is based on more decreolized varieties of AY (which, in turn, underscores the coherence of his analysis). However, in the absence of historical records, I would argue that basilectal data are needed to cast light on earlier stages of AY.

\section{Possible traces of Portuguese in AY}

In this section, I return to the conclusion that it seems likely that the Afro-Bolivian slaves arrived in Mururata, Chijchipa, and Tocaña after passing through the Portuguese slave trade during the 18th century. This assumption, coupled with McWhorter's (2000:17) assertion that 
there are no diachronically Spanish-lexified creoles in the Americas because Palenquero and Papiamentu originally had Portuguese lexifiers, suggests a possible relatedness of AfroBolivian and Afro-Brazilian slaves and their speech varieties and calls for a more detailed comparison of AY and varieties of Portuguese spoken by African and African-descendant communities. I therefore look into the hypothesis of a possible Portuguese input to AY by comparing the verb phrase and the noun phrase in AY and Brazilian Vernacular Portuguese (BVP), and by considering possible lexical connections between the two languages.

A possible relatedness of Afro-Bolivian and Afro-Brazilian speech varieties is of interest in that it may add new data to the debates on the origins of BVP in general. As BVP has come to differ significantly from European Portuguese, its origins and evolution have been debated for more than a century. The principal positions involve explanations of internal language change (Chaves de Melo 1975, Naro and Scherre 2007), language contact and creolization (Holm 1987, 2004; Guy 1981), koinéization (Mello 1996), as well as irregular language transmission (Lucchesi et al. 2009). In their extensive work on Afro-Brazilian Portuguese, Lucchesi et al. (2009) propose that while creolization processes did not emerge nationwide, they may have emerged in isolated locations such as, for instance, in Helvecia, an isolated Afro-Brazilian community in rural Bahia, where a more deeply restructured variety of Portuguese has survived. Nevertheless, it is noteworthy that most of these approaches assume that a possible creolization of Portuguese must have occurred in Brazil, not elsewhere, and if lingua francas did exist in Brazilian slave communities, these must have been Africanlexified (e.g. Lucchesi et al. 2009:54-56, 64-70). A possible transplantation of a Portuguesebased contact variety originating in the Portuguese slave trade to Brazil does not seem to be taken into consideration as a possible input variety to BVP. ${ }^{23}$ Given this wide range of positions, data on another related Afro-Iberian speech variety may shed new light on the history of (Afro-) Brazilian Vernacular Portuguese.

It is, hence, not surprising that this is not the first attempt to describe the similarities between AY and Helvecia Portuguese: some of the parallels were already pointed out by Lipski (2006), who attributes them to independent and universal developments favored by the structural relatedness of the two Iberian lexifiers. Later, Lipski (2008a:183) states that 'AfroYungueño Spanish is more creole-like than the Helvécia (Brazilian) Portuguese dialect.' In view of the additional data on AY available now, however, a new comparison is due. I start out by considering those properties of AY that seem to originate directly in the structure and lexicon of Portuguese, that is, the position of the clitic pronoun and the nature of certain

\footnotetext{
${ }^{23}$ This is, in my view, as striking lacuna. Mufwene $(2008: 146)$ points out that, in contact scenarios, '[ $\left.\mathrm{t}\right] \mathrm{he}$ relevance of nonstandard varieties of the "lexifiers" ..(...).. cannot be overestimated.'
} 
lexical and functional items. In the subsequent section, I describe features of restructuring present in both AY and BVP, which add secondary evidence to the argument.

It is important to keep in mind that the divergent methodological approaches to BVP and AY yield different sets of data. While Afro-Brazilian speech varieties and BVP were analyzed principally from a sociolinguistic and quantitative point of view (Lucchesi et al. 2009), the data collected in the course of this project do not allow representative quantitative analyses. However, unless otherwise indicated, ${ }^{24}$ all features described here were documented on more than one occasion and audio-recorded in spontaneous speech, that is, they were not elicited in linguistic interviews.

\subsection{Evidence in favor of a Portuguese input}

To begin with, the position of the object clitic of the AY verb phrase is, in my view, reminiscent of clitic placement in Portuguese. In contrast to Spanish, which places the clitic pronoun either before the auxiliary (lo está dando) or after the infinitive (darlo) or the gerund (dándolo), the AY object clitic is placed after the auxiliary and immediately before the infinitive $(4 \mathrm{a}-\mathrm{d})$ or the gerund $(4 \mathrm{e})$. The Portuguese nature of this feature is discussed by both Lipski (2008:103) and Sessarego (2011b:52) but not with regard to a possible Portuguese donor variety.

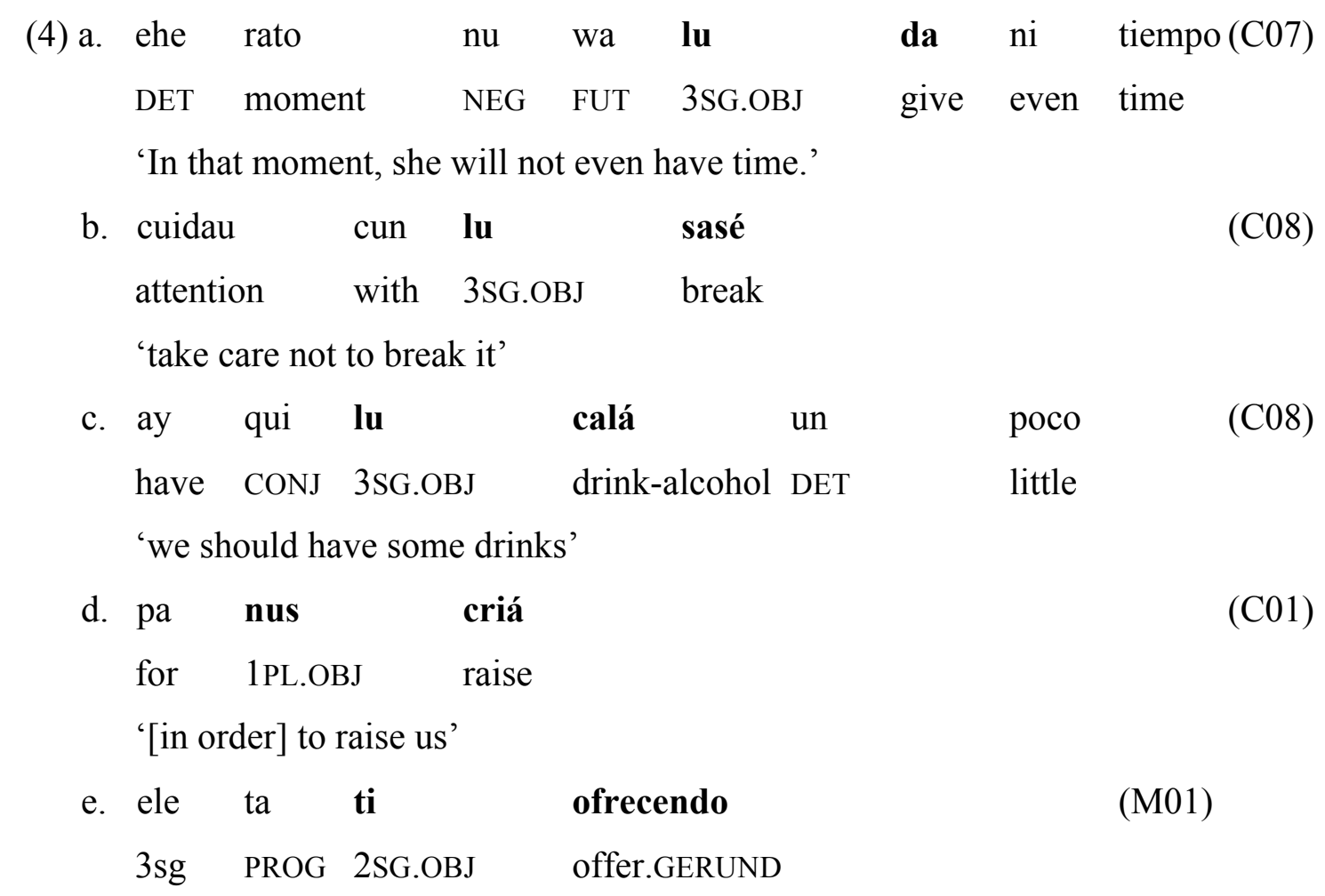

\footnotetext{
${ }^{24}$ The examples $(4 \mathrm{~b}, \mathrm{c}),(8 \mathrm{e})$, and $(10 \mathrm{c}, \mathrm{d})$ were not audio-recorded but written down in a notebook.
} 
'He is offering you [a beer].

As for examples (4a-c), Portuguese uses the pronouns $l o(s)$ or $l a(s)$ only in postposed position as in dá-lo, whereas in the preposed position $o(s)$ and $a(s)$ can be employed as in $o(s) d a r$. In AY, this preposed use of the invariant pronoun $l u$ may therefore be based on analogy between the preposed instances of $o$ and the Spanish pronoun lo. However, also in Bantu languages, one or two clitics are placed before the verb root (Hyman and Duranti 1982:221), which may corroborate a possible Bantu substrate of AY. Clitic placement of the AY verb phrase thus diverges from the Spanish lexifier and rather points to either a Portuguese or a Bantu rule. If a relexified Portuguese rule is assumed as the model of this particular syntactic feature, it would imply that some ancestors of the AY community had a fair amount of exposure to Portuguese.

Further, if we assume a Portuguese input to AY, there should be some words suggestive of a Portuguese etymon. Despite the difficulty of distinguishing between Portuguese and Spanish etyma (see discussion in Jacobs 2013:156-157), there are a few words indicative of a Portuguese origin. In the first place, AY speakers use laya 'type' and the corresponding question qué laya? 'how?' that is found among almost all Portuguese-based Asian creoles (Clements 2009:60) and hence connects AY to other Portuguese-based creole languages. Similarly, andi 'where' and quen 'who' are more likely to be of Portuguese than Spanish origin (both items are also present in West African Portuguese-lexicon creoles, Jacobs 2009:331-332), as well as també 'also', ele 's/he', cuasi 'almost' and possibly the locative marker la from Portuguese lá 'there, thereto' (see discussion below). Interestingly, these are function words that are more resistant to replacement and therefore strongly support the hypothesis of a Portuguese input to AY. Other lexical items such as ri 'laugh', lacre 'pink', iscuru 'dark (skin)', lambé 'lick' and antigo 'old' add further evidence in favor of a Portuguese input. Finally, it is noteworthy that the term prieto 'of dark skin' has survived in AY. There is therefore also lexical evidence of Portuguese being involved in the history of AY.

One morpheme may provide an additional item to this list of Portuguese elements in AY. The people from Tocaña are called tocañeros, a name that consists of Tocaña and the ethnic suffix -ero. This suffix, which refers to the inhabitants of a region or place, is not common in Bolivia because Bolivian Spanish almost exclusively makes use of Castilian endings as in paceño 'from La Paz', potosino 'from Potosi' or beniano 'from Beni'. The -ero suffix stemming from Portuguese -eiro is only found in brasilero 'Brazilian' instead of brasileño analogous to Portuguese brasileiro. The people from El Palenque de San Basilio, on 
the other hand, who are assumed to have spoken a variety of Portuguese originally, are called palenqueros with the same suffix. ${ }^{25}$ The use of this suffix in tocañero ${ }^{26}$ also contrasts with other ethnic names in the region, such as mururateño or chijchipeño, and suggests that the forefathers of the tocañeros were either Portuguese-speaking or considered - by themselves or others - to be descendants of an ethnic group that was associated with the Portuguese language, such as Brazilians.

\subsection{Evidence in favor of parallel restructuring in $A Y$ and $B V P$}

In addition, there are other properties of AY that can be adduced here because of their similarities with Africanized varieties of BVP. Even though I disagree with Sessarego in that I claim that AY is not only the result of naturalistic L2 acquisition but rather an offspring of a more deeply restructured contact variety, I do agree that many AY features did result from the grammaticalization of L2 acquisition. Therefore, the properties described in this section do not suggest a Portuguese input as such, but in consideration of their parallels with BVP and Africanized varieties of Portuguese, they add further evidence to the data presented above. The aspects of the verb phrase considered here are: (1) the conjugation paradigm, (2) the form of the conjugated verb, (3) the use of present tense forms to express the past, (4) the lack of the subjunctive mood, (5) the omission of the copula, and (6) the absence of reflexive pronouns. Finally, I will also refer to the similarities concerning number and gender agreement in both varieties as well as lexical items from African substrates.

To begin with the verb phrase, it is evident that person and number agreement is very rare in basilectal AY: one invariant verb form based on the 3rd person singular replaces the entire conjugation paradigm, specifying number and person usually by the overt subject pronoun if the context is not self-explanatory. The same rule applies to the preterite imperfect and the preterite perfect tenses. Similarly, many Africanized varieties of Portuguese show a reduction of the verbal inflection, that is, they predominantly use the verb forms of the 1 st and 3rd person singular (Guy 1981:105-106; Holm 1987:420; Mello 1996). However, among elderly speakers of the Helvécia dialect in Southern Bahia, the 3rd person singular is sometimes used as an unmarked invariant verb form for the entire conjugational paradigm (Baxter 1997:269; Lucchesi et al. 2009:356). The same was observed among the Tongas, descendants of a slave community in São Tomé, who were speakers of L2 Portuguese and

\footnotetext{
${ }^{25}$ Note that the people from Palo Monte are called Paleros with the same Portuguese suffix (Schwegler \& RojasPrimus 2010).

${ }^{26}$ Nick names in Tocaña often add - era to male personal names, which results in, for instance, Calera instead of Carlos. This suffix may belong to similar processes of marking ethnic belonging with a suffix.
} 
Umbundu, a Bantu language (Lopes \& Baxter 2011:42). The sociolinguistic distribution of this feature among the older generation and its presence in old Afro-Brazilian song lyrics (Lucchesi et al. 2009:336-337) induced some linguists such as Mussa (1991, quoted in Baxter 1997:270) to propose that the Afro-Brazilian verb was earlier completely unmarked for person and number. Mussa's strong claim may be supported by facts from both Helvécia Portuguese and basilectal AY, which both tend to reduce the verbal paradigm drastically as shown in (5):

$\begin{array}{lll}\text { (5) a. } & \text { Basilectal AY } & \text { HP } \quad \text { (Baxter 1997:269) } \\ \text { 1SG } & \text { yo abla } & \text { eu falo (fala) } \\ \text { 2SG } & \text { oté abla } & \text { você fala } \\ \text { 3SG } & \text { ele abla } & \text { ele/ela fala } \\ \text { 1PL } & \text { nohotro abla } & \text { nós/a gente fala (falamo) } \\ \text { 2PL } & \text { otene abla } & \text { vocês fala (falam) } \\ \text { 3PL } & \text { eyu(s) abla } & \text { eles/elas fala (falam) }\end{array}$

b. AY HP

$\begin{array}{lll}\text { 1SG } & \text { yo abló } & \text { eu falou (falei) } \\ \text { 2SG } & \text { oté abló } & \text { você falou } \\ \text { 3SG } & \text { ele abló } & \text { ele/ela falou } \\ 1 \mathrm{PL} & \text { nohotro abló } & \text { nos/a gente falou (falamo) } \\ \text { 2PL } & \text { otene abló } & \text { vocês falou (falaro) } \\ \text { 3PL } & \text { eyu(s) abló } & \text { eles/elas falou (falaro) }\end{array}$
c. yo jue la chumi
$1 \mathrm{SG}$ went.3SG LOC bush

'I went in the forest'
d. Nohotro vinió buscá tío Ramón.
1PL came.3SG search uncle Ramón

'We came to look for Uncle Ramón.'
e. yo
ta
yorando.
$1 \mathrm{SG}$
be. $3 \mathrm{SG}$
cry.GERUND

'I am crying.'

f. nohotro yora, mi mamá yora 'speak' 
$1 \mathrm{PL} \quad$ cry.3SG 1SG.POSS mother cry.3SG

'When we cried, our mother cried.'

Lipski (2008a:192) discusses a possible lack of subject-verb agreement as a marker of creolestatus and concludes that ' 1 st person singular and/or plural always carries [an agreement marker] ${ }^{27}$ The data presented here contradict Lipski's finding, thus providing additional evidence not to dismiss the possibility of recognizing AY as a descendant of a creole.

Concerning the morphology of the AY verb, it is noticeable that the AY paradigm lacks the diphthong in the 3rd person singular and the gerund, as required in the Spanish paradigm.

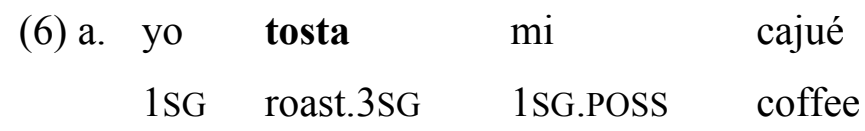

'I roast my coffee'

b. pero ti interran

but 2SG.OBJ bury.3PL

'but they bury you'

c. yo no probo cerveza

$1 \mathrm{SG}$ NEG try.3SG beer

'I do not drink beer'

d. cuerpo move

body move.3SG

'the body shook'

e. abía qui ir batendo

had.3SG CONJ go beat.GERUND

'[we] had to cut [the bush] while we walked'

f. carro ta subindo

truck be.3SG come-up.GERUND

'The truck is coming up [the hill].'

This can be the result of either the regularization of the conjugation paradigm due to incomplete L2 acquisition or the influence of a Portuguese model, which, in contrast to

\footnotetext{
${ }^{27}$ In fact, Lipski (2008a:192) notices that in preterite verb forms, regularized 3rd person verb forms do appear. The examples here show that the same occurs in present tense verb forms. However, the past tense favoring the lack of agreement was also observed in the Portuguese of the Tongas (Lopes \& Baxter 2011:47).
} 
Spanish, lacks diphthongs in verb forms. In my view, both processes are involved here. On the one hand, given the consistency of this rule in two different verbal paradigms and the fact that the present tense 3rd person singular is more frequent (Michaelis 2000:175) and the default form most readily applicable, for instance, in immigrant Spanish (Clements 2009:134), I would argue that this rule is not rooted in L2 acquisition but in the Portuguese system. On the other hand, the presence of certain exceptions to this rule in verbs with the $i e$ - diphthong such as viene 'come' and tiene 'have' illustrate, in my view, processes of L2 acquisition, which are involved in contact scenarios. They, too, support the claim of the Portuguese rule: given that some of these verbs also generalize this diphthong in their infinitive and preterite as, for instance, pierdé 'to lose' and pierdió 'lost', I hypothesize that the original Portuguese form was first replaced by its Spanish counterpart on the basis of the more frequent $3 \mathrm{sg}$ form (Portuguese perde was substituted by Spanish pierde), and then the Spanish rule of [+diphthong] was applied to Portuguese [-diphthong] in both conjugated and infinitival verbs similar to processes of hypercorrection. This is also attested in decreolized varieties of AY, in which forms such as quieriendo are used, which combine the correct Spanish diphthong of the gerund ending with the hypercorrect -ie-diphthong of the root.

Further, even though PRETERITE is usually marked by the invariable preterite verb form in the 3rd person singular, older AY speakers sometimes employ verb forms derived from the Spanish (or, perhaps, Portuguese) present tense when referring to the past. Baxter (1998:275) points out that the same occurs among elderly Helvécia Portuguese speakers as in Eu pega Mário e mandou ele cortá 'I took Mario and sent him to cut' or Meu pai é de cativeiro 'My (deceased) father was from the days of slavery'.

$\begin{array}{llllllll}\text { a. ante yo sabe } & \text { escuchá, } & \text { tenía } & \text { un } & {[\ldots]} & \text { (C01) } \\ \text { Before 1SG } & \text { know.3SG listen, } & \text { had.3SG } & \text { DET }[\ldots] \\ \text { 'Before, I used to listen, I had a [...]' } & & & & \\ \text { b. } & \text { cuando } & \text { yo } & \text { sinti } & \text { aguacero, } & \text { ponió } & \text { yové } & (\mathrm{M} 02) \\ & \text { When } & 1 \mathrm{SG} & \text { feel.3SG } & \text { rain } & \text { put.3SG } & \text { rain }\end{array}$

'Suddenly I felt the rain, it started to rain.'

A rather Romance-specific property of AY, in contrast, is the lack of subjunctives:
a. ante
qui
wawa
nace
before
CONJ
child
be-born.3SG 
'before the baby is born'

b. dicilu qui viene

tell.IMP.OBJ CONJ come.3SG

'Tell him to come.'

c. dicilu a tu mama qui va

tell.IMP.3OBJ to 2SG.POSS mother CONJ go.3SG collect-coca

'Tell your mother to collect coca leafs!'

d. ohala vivi aquí la chumi $\quad$ (T02)

hopefully live.3SG here LOC bush

'if he lived here in the forest'

e. $\mathrm{Nu}$ asti gansiá!

NEG IMP hoard

'Do not hoard!'

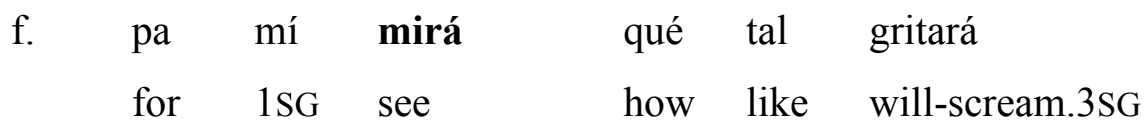

'so I can see how she screams'

g. pa euys regalá

for 3PL give-present

'for them to give a present'

Of course, the features shown in $(8 \mathrm{a}-\mathrm{c})$ are also typical of incomplete L2 acquisition and therefore not directly indicative of Portuguese rules underlying AY. Nevertheless, also in basilectal BVP, the subjunctive is still often substituted by the corresponding indicative (Mello 1996:129; Lucchesi et al. 2009:401). Examples (8a-c) show that in AY, the corresponding indicative form replaces the mandatory subjunctive as well. Further, the protasis (8d) begins with the conjunction ohala instead of $s i$ and is followed by the indicative. This is noteworthy in view of the fact that both ojalá and si require subjunctives (the latter in its preterite form), and that the original adverb ojalá (or Portuguese oxalá) 'hopefully' changed its original function to an item that corresponds to the conjunction 'if'. However, these features do not suggest a Portuguese model but add more details to the description of AY as a variety highly influenced by language contact.

$(8 \mathrm{e}-\mathrm{f})$, on the other hand, do suggest the persistence of Portuguese rules. (8e) shows that the subjunctive needed in negative imperatives is substituted by the auxiliary asti from archaic Spanish - or Portuguese - has de 'you should' followed by an infinitive. This 
indicates that, similar to fini (Detges 2000:143), also this item changed both its original form and function in AY: the usually conjugated auxiliary haber de, which suggests IMPERATIVE or PROBABILITY in both Spanish and Portuguese (similar to must or should in English), became an invariant marker of IMPERATIVE (with a meaning closer to have to). In other words, this item represents another case of grammaticalization in AY. The final clause $(8 \mathrm{f}, \mathrm{g})$ is very rare in Spanish and was reported only in certain rural Caribbean varieties, such as the Dominican Republic (Alba 2004:126) and Cuba (Lipski 2007:259). However, it is interesting that neither of these instances is discussed in the light of a possible Portuguese rule. ${ }^{28}$ Alba (2004:126) describes this phenomenon as the subject that immediately precedes the infinitive, and Lipksi as the absence of subjunctive constructions (Lipski 2007:259). Given its appearance in AY with its possible Portuguese input, I propose that this feature is more likely to originate in the Portuguese personal infinitive.

Another noteworthy feature of the AY verb phrase is the occasional absence of copulas. In fact, the omission of the copula is a feature common to many Afro-American language varieties such as Caribbean Vernacular Spanish or African American English (Holm 2004). In BVP, the copula is sometimes missing, too, as in eu_minino 'I was a boy' or ela loka pur eli 'she's crazy for him' (Holm 2004:83). Likewise, AY speakers frequently omit the copula as in (12e) and the following examples:

$\begin{array}{llllll}\text { a. } & \text { su } & \text { pie } & \text { como gancho } & & \\ & \text { 3SG.POSS foot } & \text { like } & \text { hook } & & \\ & \text { 'His leg is very long.' } & & & & \\ \text { b. } & \text { sus } & \text { wawita } & - & \text { bonito, } & \text { bien bonito } \\ & \text { 3PL.POSS child } & & \text { cute, } & \text { well cute. }\end{array}$

'Her children are cute, very cute.'

Furthermore, it is worth noting that reflexive verbs lack the reflexive pronoun in both AY and BVP. Mello (1996:153) explains that BVP employs personal subject pronouns to replace reflexive pronouns; to disambiguate the utterance, many speakers would then add mesmo 'self'. The example she provides is João cortou ele (mesmo) com faca 'John cut himself with a knife'. Likewise, AY often lacks reflexive pronouns with verbs which require them in Spanish:

\footnotetext{
${ }^{28}$ Alba only attributes double negation in Dominican Spanish to a 'primitive afro-portuguese code' (2004:144, my translation).
} 


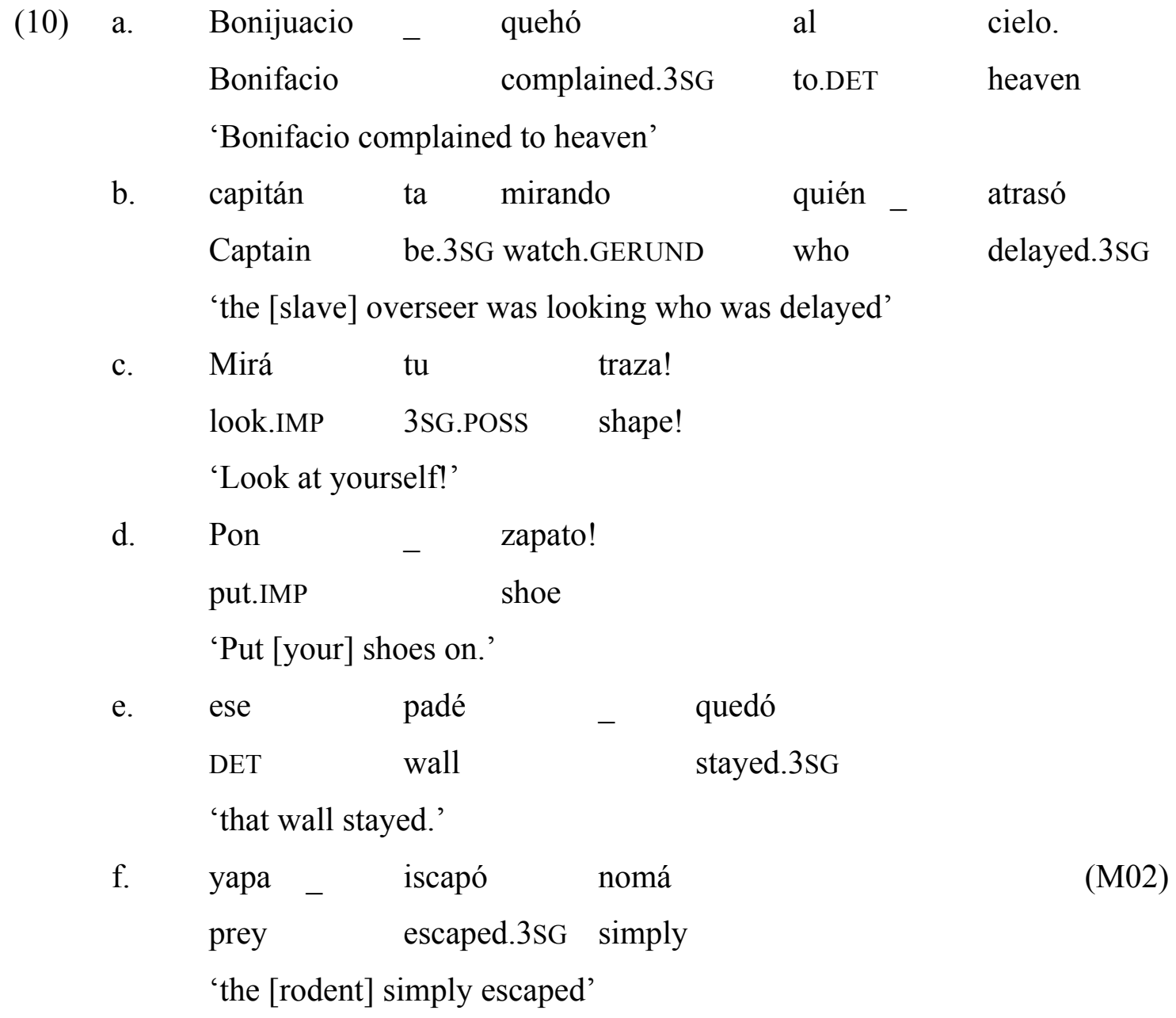

In addition, the restructuring of the noun phrase is common in creolized language varieties. The inflectional morphology of gender and number as well as the use of definite articles present in the lexifier language is rarely maintained categorically in creoles. The noun phrase of Helvécia Portuguese also experienced considerable restructuring in the past. Based on the sociolinguistic distribution of variation in gender and number agreement among elderly speakers, it seems possible that Helvécia Portuguese may have completely lacked gender and number agreement in earlier stages of the history of that community. Similarly, the use of a definite article is becoming more frequent among younger speakers as they approximate more normative varieties of Brazilian Portuguese, while the oldest generation displays a lack of definite articles in nearly half of the instances (Lucchesi et al. 2009:322). The AY noun phrase was restructured in this respect too. As examples $(11 \mathrm{a}-\mathrm{c})$ illustrate, there seems to be only one indefinite article $u n$ and possibly no definite article in basilectal AY. Rather, noun phrases that require a definite article often use the demonstrative pronoun ese/ehe 'this' or any possessive pronoun or a numeral (the use of the Spanish masculine definite article together with nouns of feminine gender in Spanish, as in el clave, occurs, in my view, only in the post- 
creole variety of AY). The feminine article la, on the other hand, does apparently exist. Lipksi (2008:84) assumes that it is a randomly used feminine article. However, given that it is mainly used in place indications as in $(5 \mathrm{c}),(8 \mathrm{~d})$, and $(11 \mathrm{c}, \mathrm{f})$ and combined with prepositions as in (11d), it would seem plausible to hypothesize that la may be an independent locative marker originating from Portuguese lá 'there; thereto'. An Aymara origin of this feature is unlikely since Aymara is an agglutinative language that makes use of locative suffixes (Hardman 2001:78-79). Moreover, examples (11b, e) illustrate that the original masculine form of adjectives and participles is generalized.

$\begin{array}{lll}\text { a. un } & \text { razai } & \text { perro } \\ \text { DET } & \text { race.of } & \operatorname{dog} \\ \text { 'a dog breed' } & & \end{array}$
b. no taba clavau calamina
NEG was.3SG nailed corrugated-iron

'The corrugated iron was not nailed on [the roof].'

$\begin{array}{llllll}\text { c. nohotro } & \text { tenía } & \text { un } & \text { reunión } & \text { la } & \text { escuela (M02) } \\ 1 \mathrm{PL} & \text { had.3SG } & \text { DET } & \text { meeting } & \text { LOC } & \text { school }\end{array}$

'We had a meeting at the school.'
d. ese maceta de la su puerta

DET flowerpot from LOC 3SG.POSS door

'that flowerpot at her door'

\begin{tabular}{|c|c|c|}
\hline ta & sano & tu \\
\hline be. $3 \mathrm{SG}$ & healthy & 2SG.POSS \\
\hline
\end{tabular}

'Your mother is healthy.'

\begin{tabular}{|c|c|c|c|c|c|}
\hline ese & señora & ti & metía & la & comedor \\
\hline DET & lady & 2SG.OBJ & put.3SG & LOC & dining-room \\
\hline
\end{tabular}

'The lady put you in the dining-room.'

As for plural marking in basilectal AY, examples $(12 \mathrm{a}, \mathrm{b})$ show that, generally, plural is marked only once with either the invariant article $l u(s)$ or a numeral. Many mass nouns such as gente 'people' are countable in AY. The plural marker $l u$ can be combined with the invariant demonstrative pronoun ese/ehe 'this' and all possessive pronouns as in examples $(12 \mathrm{c}-\mathrm{e})$, thus providing additional evidence of the presence of isolated and combinable grammatical morphemes in AY. 


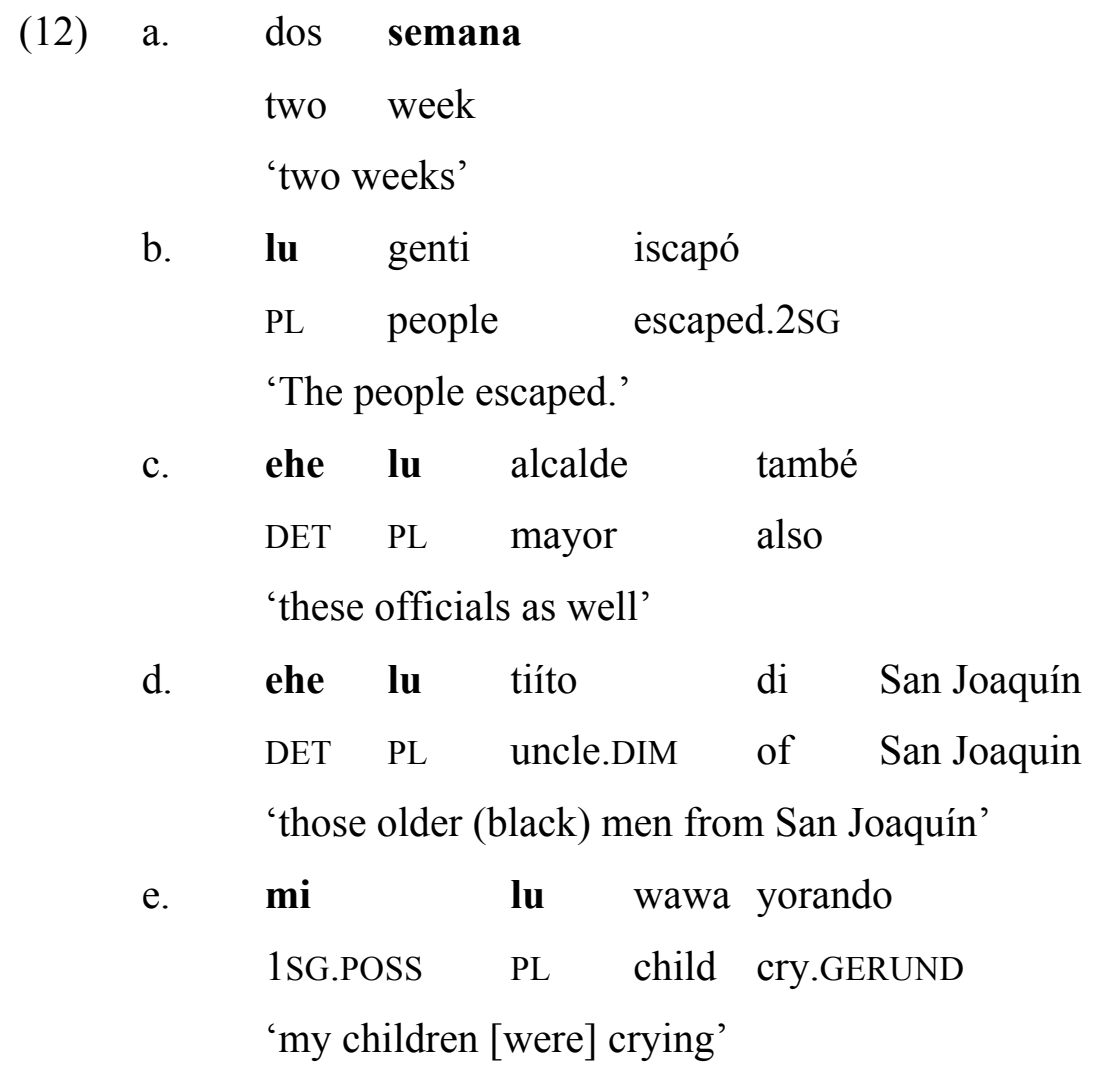

Similarly, most BVP varieties show variation in number agreement. In contrast to more normative varieties of Portuguese, BVP shows a tendency to mark plural number only once or twice at the beginning of the noun phrase whilst the rest remains unmarked as in as casa branca 'the white houses' (Guy 1981:102-3). Mello (1996:114) ventures a general rule for plural marking in BVP as simple as 'mark the leftmost element', a rule which can be applied to all sentences, even those which start with interjections such as ohs menino_! 'hey, boys!' or pronouns such as ques gatinho_danado_ 'what naughty pussycats'. Similar processes were documented in Helvecia as well as Tonga Portuguese by Baxter (Lucchesi et al. 2009:277). As Guy explains, most African substrate languages, be they Bantu, Yoruba, or Kwa, among others, mark plural at the beginning of a NP with either a prefix or a clitic (Guy 1981:300303), which indicates that this feature may stem from an African substrate. An Aymara origin of this structure is rather unlikely, because Aymara, an agglutinative language, marks plural (not obligatorily) with the suffix - naka (Hardman 2001:141). At the same time, possessives are equally placed at the end of the root in Aymara (Hardman 2001:142), which, again, indicates that Aymara was probably not the model of the AY noun phrase. Rather, this highly reduced use of plural agreement in AY parallels the structure of the noun phrase in AfroBrazilian and African varieties of Portuguese. 
Gender agreement, on the other hand, is more widespread in BVP than number agreement. However, several Afro-Brazilian communities in different parts of Brazil display variation in gender agreement (Lucchesi et al. 2009:305). As for Helvecia Portuguese, the considerable variation in gender agreement among elderly speakers indicates that the lack of gender agreement was probably more common in earlier stages of Helvécia Portuguese (Baxter \& Lucchesi 1999; Lucchesi et al. 2009:309). As the system of basilectal AY and earlier forms of BVP are in many respects very similar, it seems justified to assume that they originated in similar settings, namely places where Bantu and a contact variety of Portuguese coexisted and influenced each other.

A small number of African lexemes can be added to the discussion here. Contrary to Lipski's (2008a:52) statement that 'there are no words of undisputed African origin', there are a few African items in AY. Even though they still call for a more detailed analysis, the terms ñanga 'crybaby', chinga 'annoying', and probably mama and tata with the corresponding mama grande 'grandmother' and tata grande 'grandfather, ${ }^{29}$ among some ritual designations such as semba 'belly dance' and gandingo 'small Saya drum' do point at an African origin. While vestiges of ñanga from Kikongo ngyangya are only documented in the Caribbean (for instance, chango 'hypocrite' in Puerto Rico, Álvarez Nazario 1991:387), xinga with a similar meaning (Megenney 1998:91) and semba (Ortiz Oderigo 2008:81) do exist in BVP and the River Plate as well. These terms hence give evidence to two conclusions concerning the origins of AY speakers: first, ñanga and semba from Kikongo point to a Bantu origin of the Afro-Bolivian community, which is consistent with the existing African family names Angola and Maconde and Father Chomé's description of the slaves in Buenos Aires. Second, as semba and chinga exist in Brazil and the River Plate as well, they support the hypothesis of the slave trade route to the Yungas valleys via the River Plate. Both conclusions imply that AY speakers may have arrived from Portuguese slave trading settlements and may have had contact with the Portuguese language before. They thus lend further support for the idea of a Portuguese input to AY. Of course, most of the features outlined here are also found in other African American language varieties and hence not unique to AY and BVP. However, certain features, such as the missing diphthong (6a-f) and maybe the final construction in sentence (8f, g), are difficult to attribute to a language other than Portuguese.

\section{Discussion}

\footnotetext{
${ }^{29}$ These words were replaced by Aymara awicho 'grandmother' and Spanish awelo 'grandfather'.
} 
Until now, the knowledge of the past of the small Afro-Bolivian community was too vague to reliably determine the roots of AY and the conditions under which it evolved. Earlier studies offered conflicting answers: decreolization from an earlier (semi)creole with an AfroHispanic pidgin ancestor (Lipski 2008a) or naturalistic L2 acquisition with neither a pidgin nor a creole ancestor (Sessarego 2011b). Research into the culture, history, and language of the small Afro-Yungueño community of Mururata and nearby Chijchipa and Tocaña as part of the present study has shed new light on the possible origins of AY. According to the evidence available, I proposed that it is more likely that most of the slaves arrived in the Mururata hacienda in the Yungas valleys during the 18th century via the River Plate on the Angola-Brazil route directly from the Portuguese slave trade centers. This indicates that the forefathers of AY speakers had been in contact with some variety of (Afro-) Portuguese before their arrival, which would imply that Portuguese was involved as a potential donor variety of AY. The living conditions of Afro-Bolivians on the hacienda of Mururata in social, geographic, and attitudinal isolation then favored the maintenance of traits of the imported language for more than 200 years until the second half of the 20th century, when the community intensified its contact with its wider social and linguistic environment after the Reforma Agraria. The AY speech community of Mururata, Chijchipa, and Tocaña hence has similar origins and social history as certain communities of African descent in Brazil, and the assumption of Portuguese being involved in its history calls for a comparison of AY with varieties of Afro-Brazilian Portuguese.

To find linguistic evidence supporting this hypothesis, I compared AY with vernacular Brazilian varieties of Portuguese, and the structures of AY and some Afro-Brazilian varieties match in many respects. The placement of the verb clitic, for instance, corresponds to the Portuguese rule and is likely to originate in that language - if not in a Bantu substrate. Similarly, there are both lexical as well as grammatical items, above all cuasi, ele, andi, també, qui laya, antigo, and arguably the locative marker la, that stem from Portuguese and provide evidence in favor of the assumption that Portuguese was a donor variety of AY. In addition, the verb forms of the present and gerund without the Spanish diphthong, as well as the subordinate clause pa eyus regalar, correspond, in my view, rather to Portuguese than to Spanish.

Finally, there are other structural similarities that are also found in restructured African influenced varieties of BVP, and which underscore this assumption. The omission of the copula, for instance, the use of present tense verb forms in past tense contexts, the frequent absence of the definite article, and the lack of subjunctives and reflexive pronouns 
can be found in rural Afro-Brazilian varieties as well, which suggests that similar processes of language contact and L2 acquisition had been involved. In addition, the sociolinguistic distribution of certain divergent BVP features shows that variation in agreement rules is more common among elderly speakers, which may represent earlier stages of BVP. In sum, there is both structural as well as lexical evidence that supports the assumed historical relationship between speakers of Afro-Brazilian Portuguese varieties and AY and corroborates the hypothesis of a Portuguese input to AY. I therefore submit that the donor varieties of AY were a Portuguese contact variety, African substrate languages, the Spanish lexifier, and the Aymara adstrate.

The assumption that AY has an 18th century Portuguese ancestor has a number of implications for the study of AY and other restructured Iberian varieties. First, to categorize AY as an Afro-Hispanic contact variety with a Portuguese input does not support Lipski's (2008:45) hypothesis that AY stems from a 16th century Afro-Hispanic pidgin ancestor. Instead, it seems that AY did not exist in the Yungas region before the arrival of the first slaves in the 18th century. The fact that AY mainly consists of Spanish and Aymara vocabulary today does not contradict the assumption of a Portuguese input since the considerable body of Aymara lexemes in AY (the exact number of which has yet to be determined) indicates that the AY lexicon evolved afterwards in situ on the basis of the available founder varieties. In fact, I would argue that a part of the Aymara items were introduced by the slave overseers, who were supposed to know Aymara and who may have spoken a deficient L2 variety thereof with the workers. This assumption is supported by the fact that there seems to be relatively little Aymara influence on the grammar of AY. The structure of the noun phrase with the pre-nuclear independent pluralizer $l u$, for example, is more likely of African than Aymara origin, which illustrates that, structurally, Aymara influenced mainly the post-creole varieties of AY but not its basilect. Rather, apart from the Portuguese input, there is evidence to assume that Kikongo was one of the substrate languages of AY.

At the same time, the assumption that Portuguese was involved in the emergence of AY provides another example of McWhorter's (2000) claim that there are no originally Spanish-lexified creoles. This is in line with the view of a Portuguese input to Papiamentu and Palenquero, as claimed, for instance, by Jacobs (2009) and Schwegler (1999), respectively. Nevertheless, the presence of possible Portuguese structures such as the personalized infinitive in rural Afro-Cuban or Afro-Dominican dialects as well as certain phonological and lexical similarities suggest that a Portuguese input could also be valid for these varieties. I 
therefore submit that future research should also consider more carefully a possible Portuguese input to other Afro-Hispanic non-standard varieties, such as Dominican or Cuban bozal Spanish, not only creoles.

On the other hand, the assumption of a Portuguese donor variety of AY also adds new inputs to the discussion of restructured varieties of Portuguese. For example, Lucchesi et al. (2009) assess the question of a possible creolization of earlier stages of BVP assuming that creolization processes must have occurred in Brazil, not elsewhere (Lucchesi et al. 2009:5456). Given the possibility of a Portuguese input to AY that was transplanted to Bolivia in the course of the 18th century, I raise the question of whether the most divergent varieties of rural Afro-Brazilian Portuguese, such as Helvecia Portuguese, were not equally imported to Brazil from Portuguese-speaking settlements and not only formed in situ. Such a scenario would imply that AY and Afro-Brazilian Portuguese varieties may have had a similar input variety. In the light of the structural and lexical similarities between these (and other) varieties as well as McWhorter's Afrogenesis Hypothesis (2000), one such input variety may have been - apart from African languages and African Portuguese-based creoles, of course - a Portuguesebased contact variety, which could have been used among traders in the Atlantic slave trade. In fact, Schwegler (fc.) explores the possibility of such a scenario on the basis of a 'deep feature', the pronoun ele, and concludes that multilingualism was probably very common in the Atlantic slave trade, and that a slave trade pidgin may have existed.

Finally, this connection between AY and BVP is also insightful with regard to the mapping of the geographic distribution of African-Iberian speech varieties (Schwegler 2002:127). If the relatedness between AY and Afro-Brazilian varieties of Portuguese is assumed, the study of Atlantic Portuguese-based creoles and their speech communities should not only focus on coastal areas and the Caribbean but also include the small AY speech community in the Bolivian Andes. At the same time, comparative diachronic research on the vestiges of Afro-Hispanic varieties of the River Plate region, that is, Uruguay, Paraguay, and Argentina, should consider possible connections to AY and BVP, a task that was started by Lipski (2008a:175, 2008b) and must be developed further. However, in spite of the usefulness of such comparative studies, it is also important to consider isolated communities as independent scenarios, as upheld by Winford (2000) and Lucchesi et al. (2009), because the focus on an individual community may often allow deeper insights into its origins than historical demographic data of an entire nation.

To conclude, it is important to stress that our understanding of certain AY structures has just begun. For future research it is necessary to provide a more complete description of 
AY and its varieties, its creole features, as well as the differences between AY and its immediate contact variety, Aymara-influenced Andean Spanish. Further, it will be of interest to look beyond Brazil and see whether parallel structures between AY and the Portuguesebased creoles in West Africa can be found. Some lexical items, such as andi or the possible existence of $m i$, point in this direction. On the other hand, a thorough comparison of basilectal AY and Palenquero and other Afro-Hispanic varieties spoken in the Caribbean, above all Cuban bozal Spanish and palero, is due. As for now, I claim that it seems reasonable to assume that Portuguese was involved in the history of AY, and that AY and Afro-Brazilian Portuguese varieties seem to have a similar social history and a common donor variety.

\section{References:}

Agar, Michael H. 2008. The Professional Stranger. An informal Introduction to Ethnography. 2nd ed. Bingley: Emerald Publishing.

Alba, Orlando. 2004. Cómo hablamos los dominicanos: un enfoque sociolingüístico. Santo Domingo: Grupo León Jimenes.

Alleyne, Mervyn C. 2000. Opposite processes in “creolization”. In Neumann-Holzschuh, Ingrid and Edgar W. Schneider (eds.), 125-133.

Álvarez Nazario, Manuel. 1991. Historia de la lengua española en Puerto Rico. Santo Domingo: Editora Corripio.

Angola Maconde, Juan. 2000. Raices de un pueblo. Cultura afroboliviana. $2^{\text {nd }}$ ed. La Paz: Producciones CIMA.

Baxter, Alan. 1997. Creole-like features in the verb system of an Afro-Brazilian variety of Portuguese. In Arthur K. Spears \& Donald Winford (eds.). The structure and Status of Pidgins and Creoles. Creole Language Library 19, 265-288. Amsterdam/Philadelphia: Benjamins. . 1998. "Morfosintaxe do Português vernáculo do Brasil.” In Matthias Perl \& Armin Schwegler (eds.). América negra: panorámica actual de los estudios lingüísticos sobre variedades hispanas, portuguesas y criollas, 97-134. Frankfurt: Vervuert.

Baxter, Alan \& Dante Lucchesi. 1999. El pasado criollo del dialect afro-brasileño de Helvécia. In Klaus Zimmermann (ed.), 503-523.

Bowser, Frederick P. 1974. The African Slave in Colonial Peru. 1524-1650. Stanford: Stanford University Press.

Bridikhina, Eugenia. 1995. La mujer negra en Bolivia. La Paz: Ministerio de Desarrollo 
Humano.

Busdiecker, Sara. 2006. We are Bolivians, too. The Experience and Meaning of Blackness in Bolivia. Ann Arbor: University of Michigan PhD dissertation.

Cariaga, Juan. 2008. Mururata. La Paz: La Razón.

Carricaburo, Norma. 1999. El voseo en la Literatura Argentina. Madrid: Arco Libros.

Chaves de Melo, Gladstone. 1975 [1946]. A língua do Brasil. $3^{\text {rd }}$ ed. Rio de Janeiro: Getulio Vargas.

Clements, J. Clancy. 2009. The Linguistic Legacy of Spanish and Portuguese. Colonial Expansion and Language Change. Cambridge: Cambridge University Press.

Crespo, Alberto. 1995 [1977]. Esclavos negros en Bolivia. $2^{\text {nd }}$ ed. La Paz: Librería Editorial Juventud.

Detges, Ulrich. 2000. Two types of restructuring in French creoles: A cognitive approach to the genesis of tense markers. In Neumann-Holzschuh, Ingrid and Edgar W. Schneider, $135-162$.

Fernández, Mauro (eds). 2004. Los criollos de base ibérica. ACBLPE 2003. Madrid: Iberoamericana.

Haas, Mary R. 1976. Anthropological linguistics: History. In Anthony F. C. Wallace, J. Lawrence Angel, Richard Fox, Sally McLendon, Rachel Sady \& Robert Sharer (eds.) Perspectives on Anthropology 1976. Arlington: American Anthropological Association.

Hardman, Martha J. 2001. Aymara. Munich: Licom.

Harrison, K. David. 2007. When languages die. The extinction of the World's Languages and the Erosion of Human Knowledge. Oxford: Oxford University Press.

Holm, John. 1987. Creole influence on Popular Brazilian Portuguese. In Glenn G. Gilbert (ed.), Pidgin and Creole Languages. Essays in Memory of John E. Reinecke, 406-429. Honolulu: University of Honolulu Press. . 2004. Languages in Contact. The Partial Restructuring of Vernaculars. Cambridge: Cambridge University Press.

Hyman, Larry M. and Alessandro Duranti. 1982. On the object relation in Bantu. Syntax and Semantics, 15, 217-239.

Guy, Gregory R. 1981. Linguistic Variation in Brazilian Portuguese: Aspects of the Phonology, Syntax, and Language History. Philadelphia: University of Pennsylvania $\mathrm{PhD}$ dissertation.

Jacobs, Bart. 2009. The Upper Guinea Origins of Papiamentu. Diachronica 26:3, 319-379. 
2013. Reassessment of the Portuguese contribution to the Papiamentu lexicon. Journal of Pidgin and Creole Languages, 28(1), 154-165.

Labov, William. 1972. Sociolinguistic Patterns. Philadelphia: University of Pennsylvania Press.

Leons, Barbara. 1978. Race, Ethnicity and Political Mobilization in the Andes. American Ethnologist 5(3). 484-494.

Lopes, Norma da Silva and Alan N. Baxter. 2011. A concordância verbal variável no português dos tongas. Papia, 21(1), 39-50.

Lipski, John M. 2005. A history of Afro-Hispanic Language. Five Centuries, Five Continents. Cambridge: Cambridge University Press.

. 2006. Afro-Bolivian Spanish and Helvécia Portuguese: Semi-Creole Parallels. Papia 16. 96-116. .2007. El Español de América. 5th ed. Madrid: Cátedra. . 2008a. Afro-Bolivian Spanish. Madrid: Iberoamericana. . 2008b. Afro-Paraguayan Spanish: The Negation of Non-Existence. The Journal of Pan African Studies, 2(7), 1-37.

Lucchesi, Dante. 1999. A variação na concordância de gênero em dialetos despidginizantes e descrioulizantes do português do Brasil. In Klaus Zimmermann (ed.), 477-502.

Lucchesi, Dante, Alan Baxter \& Ilsa Ribeiro (orgs.). 2009. O português afro-brasileiro. Salvador da Bahia: EDUFBA.

McWhorter, John H. 2000. The Missing Spanish Creoles: Recovering the Birth of Plantation Contact Languages. Berkeley: University of California Press. .2005. Defining Creole. New York: Oxford University Press.

Mendoza, José G. 1991. El castellano hablado en La Paz. Sintaxis divergente. LPZ: Facultad de Humanidades y Ciencias de la Educación.

Megenney, William. 1998. A relevância das línguas africanas no português do Brasil. In Matthias Perl \& Armin Schwegler (eds.), 97-134.

Mello, Heliana Ribeiro de. 1996. The Genesis and Development of Brazilian Vernacular Portuguese. New York: CUNY PhD dissertation.

Mello e Souza, Marina de. 2002. Reis negros no Brasil escravista. História da festa de coroação de rei congo. Belo Horiyonte: UFMG.

Michaelis, Susanne. 2000. The fate of subject pronouns: Evidence from creole and non-creole languages. In Neumann-Holzschuh, Ingrid and Edgar W. Schneider (eds.), 163-184. 
Montaño Aragón, Mario. 1992. La familia negra en Bolivia. Chap. 37 of Guía etnográfica y lingüistica de Bolivia. Tribus del altiplano y valles. Vol. 3. La Paz: Editorial Don Bosco.

Mufwene, Salikoko S. 2000. Creolization is a social, not a structural, process. In NeumannHolzschuh, Ingrid and Edgar W. Schneider (eds.), 65-84. . 2001. The Ecology of Language Evolution. Cambridge: Cambridge University Press. . 2008. Language Evolution. Contact, Competition and Change. Wiltshire: Cromwell. Mühn, Juan. 1946. La Argentina vista por viajeros del siglo XVIII. Buenos Aires: Huarpes. Naro, Anthony Julius and Maria Marta Pereira Scherre. 2007. Origens do português brasileiro. São Paulo: Parábola.

Neumann-Holzschuh, Ingrid and Edgar W. Schneider (eds.). 2000. Degrees of Restructuring in Creole Languages. Creole Language Library 22, 65-84. Amsterdam/Philadelphia: John Benjamins.

Ortiz Oderigo, Néstor. 2007. Esquema de la música afroargentina. Editado por Norberto Pablo Cirio. Caseros: Universidad Nacional Tres de Febrero. . 2008. Diccionario de africanismos en el castellano del Río de la Plata. Caseros: Universidad Nacional de Tres de Febrero.

Perl, Matthias Perl \& Armin Schwegler (eds.). 1998. América negra: panorámica actual de los estudios lingüisticos sobre variedades hispanas, portuguesas y criollas. Frankfurt: Vervuert.

Perez-Inofuentes, Danae M. 2010a. Las huellas lingüisticas de África en Bolivia: el habla afroyungueña. Zurich: University of Zurich MA thesis. . 2010b. Las estrategias reivindicativas de la comunidad afroboliviana. Bulletin Suisse des Américanistes, No. 72, 49-58.

Perez-Inofuentes, Danae \& Lena Zipp. In preparation. Prosodic practices of Afro-Yungueño Spanish.

Pizarroso Cuenca, Arturo. 1977. La cultura negra en Bolivia. La Paz: ISLA.

Portugal Ortiz, Max. 1977. La escavitud negra en las épocas colonial y nacional de Bolivia. La Paz: Instituto Boliviano de Cultura.

Rey Gutiérrez, Mónica. 1998. La Saya como medio de comunicación y expression cultural en la comunidad Afroboliviana. La Paz (Bolivia): Universidad Mayor de San Andrés BA thesis.

Schreier, Daniel. 2009. Language in isolation, and its implications for variation and change. 
In Blackwell Language and Linguistics Compass 3. Oxford: Blackwell Publisher. Schwegler, Armin. 1999. Monogenesis Revisited. The Spanish Perspective. In Rickford, John and Suzanne Romaine (eds.). Creole Genesis, Discourse and Attitudes: Studies Celebrating Charlene Sato. Amsterdam/Philadelphia: John Benjamins, 235-262. . 2000. The myth of decreolization: The anomalous case of Palenquero. In Neumann-Holzschuh, Ingrid and Edgar W. Schneider (eds.), 125-133. . 2002. Creolistics in Latin America: Past, Present, and Future. In Glenn, Gilbert (ed.). Pidgin and Creole linguistics in the twenty-first century. New York: Peter Lang, 121 171.

. Fc. Spanish/Portuguese interface within five unique circumstances. In Ana M.

Carvalho and Patrícia Amaral (eds.). Portuguese/Spanish Interfaces. Amsterdam: John Benjamins.

Schwegler, Armin \& Constanza Rojas-Primus. 2010. La lengua ritual del Palo Monte (Cuba): estudio comparativo (Holguín/Cienfuegos). Revista Internacional de Lingüística Iberoramericana, 15(1), 187-244.

Sessarego, Sandro. 2011a. On the Status of Afro-Bolivian Spanish Features: Decreolization or Vernacular Universals? In Michnowicz, Jim \& Robin Dodsworth (eds.). Selected Proceedings of the $5^{\text {th }}$ Workshop on Spanish Sociolingusitics. Somerville, MA: Cascadilla Proceedings Project. . 2011b. Introcucción al idioma afroboliviano. Una conversación con el awicho Manuel Barra. La Paz: Plural Editores.

Sessarego, Sandro \& Javier Gutiérrez-Rexach. 2011. Feature valuation, variation, and minimalism: Gender in Afro-Bolivian Spanish. Iberia 3(1). 65-80.

Spedding, Alison. 1994. Wachu wachu. El cultivo de coca e identidad en los Yunkas de La Paz. La Paz: Hisbol.

Studer, Elena F. S. de. 1958. La trata de negros en el Río de la Plata durante el siglo XVIII. Montevideo: Libros de Hispanoamérica.

Thomason, Sarah. 1997. A typology of contact languages. In Spears, Arthur K. and Donald Winford (eds.). The structure and status of pidgins and creoles. Creole Language Library 19. Amsterdam/Philadelphia: John Benjamins.

Winford, Donald. 2000. "Intermediate" creoles and degrees of change in creole formation: The case of Bajan. In Neumann-Holzschuh, Ingrid and Edgar W. Schneider (eds.), 215-246.

Zimmermann, Klaus (ed.). 1999. Lenguas criollas de base lexical española y portuguesa. 
Madrid: Iberoamericana.

Statistics 2001 Census: www.ine.gob.bo 